\title{
Taxonomic review of the tree snail genus Amphidromus Albers, 1850 (Pulmonata: Camaenidae) in Laos, with the description of two new species
}

\author{
Khamla INKHAVILAY ${ }^{1}$, Chirasak SUTCHARIT ${ }^{2, *} \&$ Somsak PANHA ${ }^{3, *}$ \\ Animal Systematics Research Unit, Department of Biology, Faculty of Science, \\ Chulalongkorn University, Bangkok 10330, Thailand. \\ *Corresponding authors: jirasak4@yahoo.com; somsak.pan@chula.ac.th \\ ${ }^{1}$ Email: kinkhavilay@gmail.com \\ ${ }^{1}$ urn:1sid:zoobank.org:author:2E620B9C-48BA-48E6-A017-FE8ED2AB0E59 \\ ${ }^{2}$ urn:1sid:zoobank.org:author:C2E2FA6B-A3F9-4F33-B447-B59B1BD322D4 \\ ${ }^{3}$ urn:1sid:zoobank.org:author:AC935098-D901-4F35-A414-4B0D4FE44E79
}

\begin{abstract}
The land snail genus Amphidromus Albers, 1850 and its subgenus Syndromus Pilsbry, 1900 (family Camaenidae) in Laos are revised. Fourteen species from various habitats of deciduous forest and limestone areas throughout Laos are confirmed. The classification is revised and discussed, based on material examined from Laos, Cambodia, Vietnam and Thailand and after comparison with the type specimens in many museums. Two new species, A. (Amphidromus) syndromoideus Inkhavilay \& Panha sp. nov., from central Laos, and A. (Syndromus) xiengkhaungensis Inkhavilay \& Panha sp. nov., from northern Laos, are described and discussed.
\end{abstract}

Keywords. Limestone, Amphidromus, classification, systematics, Southeast Asia.

Inkhavilay K., Sutcharit C. \& Panha S. 2017. Taxonomic review of the tree snail genus Amphidromus Albers, 1850 (Pulmonata: Camaenidae) in Laos, with the description of two new species. European Journal of Taxonomy 330: 1-40. https://doi.org/10.5852/ejt.2017.330

\section{Introduction}

The Camaenidae family is comprised of some of the most fascinating land snails, and they occur in various habitat types in Southeast Asia. Many genera are ground dwellers but some are considered to be tree dwellers or arboreal snails, including those in the genus Amphidromus Albers, 1850. Members of Amphidromus have a conical shell (dextral and/or sinistral) and are very diverse in their shell color and banding patterns (Pilsbry 1900; Laidlaw \& Solem 1961; Sutcharit \& Panha 2006). Their distribution ranges from Assam in India to Indochina and to Sundaland, south of the Philippines, Wallacea, and a single species found in the Northern Territory of Australia (Solem 1959, 1983; Laidlaw \& Solem 1961). There are about 95 recognized species, which are classified in two subgenera (Thach 2014, 2015; Thach \& Huber 2014; Sutcharit et al. 2015 and references therein; Vermeulen et al. 2015). The nominotypical subgenus usually has a larger shell, is chirally dimorphic and has a long epiphallus and flagellum, whereas the smaller shells of the subgenus Syndromus Pilsbry, 1900 are mostly of the sinistral 
type (except two species, the enantiomorphic Amphidromus glaucolarynx (Dohrn, 1861) and the dextral Amphidromus kuehni Möllendorff, 1902) with a short epiphallus and flagellum (Pilsbry 1900; Zilch 1953; Sutcharit \& Panha 2006; Sutcharit et al. 2007, 2015).

Most members of the genus Amphidromus were named before the $20^{\text {th }}$ century, based exclusively on shell characters, and many of them are known from only a single shell or a few type specimens with rough locality information (Sutcharit et al. 2015). Because Amphidromus exhibits a high degree of variation in shell color and banding patterns, its classification is very complicated and problematic. Although several efforts on the taxonomy of Amphidromus and catalogues and illustrations of the type specimens have been provided (Fulton 1896; Pilsbry 1900; Zilch 1953; Laidlaw \& Solem 1961; Sutcharit et al. 2015), the wide range of morphological variation within Amphidromus raises doubt as to whether those previous revisionary works may be inapplicable for recent collections, especially since multiple names have been ascribed to single taxa, making species recognition confusing.

Laos is located near the center of the Indo-Burmese hotspots (Myers et al. 2000), which has a high diversity of forest types and pristine ecosystems that can potentially support a very high diversity of land snail fauna. Almost all the groups of land snails in Laos are poorly studied compared to other Indo-China countries. Only six species of Amphidromus have been reported so far from Laos: A. flavus (Pfeiffer, 1861), A. xiengensis Morlet, 1891, A. haematostoma Möllendorff, 1898, A. laosianus Bavay, 1898, A. givenchyi Geret, 1912 and A. protania Lehmann \& Maassen, 2004, compared to, for example, 19 and 23 species in Thailand and Vietnam, respectively (Panha 1996; Schileyko 2011; Sutcharit et al. 2015). The present study focused on the basic taxonomy of the tree snail genus Amphidromus in Laos. Recently collected specimens were investigated together with reference materials in several museum collections. The previous uncertain recorded species and species of vague status in Laos are redescribed based on the type specimens and the genital characters. In addition, we propose a shell banding system for describing members of the subgenus Syndromus and describe the informative genitalia and radula characters of this subgenus based on the type species. Lastly, six new records and two new and endemic species are carefully described.

\section{Material and methods}

Empty shells and living specimens were collected throughout Laos from different elevations above mean sea level (amsl) and forest types and also from fruit orchards. Living specimens were photographed before preservation, initially at $-20^{\circ} \mathrm{C}$ and subsequently in $95 \%(\mathrm{v} / \mathrm{v})$ ethanol, prior to conducting the anatomical study. Genital morphology was critically examined. Intact adult shells were measured for whorl number, shell height (h) and major diameter or shell width (d) using digital Vernier calipers (Mitutoyo, CD-6 CS). The buccal masses were removed and soaked in 10\% (w/v) potassium hydroxide solution for 3-5 hours before extracting the radula, which was then cleaned in distilled water and preserved in $95 \%(\mathrm{v} / \mathrm{v})$ ethanol. Radulae were examined by scanning electron microscopy (SEM: JEOL, JSM-5410 LV), recording the formula and shape of the teeth.

The type locality is mentioned from the original publication in the original wording and language. If possible, the modern name and/or regional names of the type locality are provided in square brackets.

\section{Abbreviations}

The terms proximal and distal are used for the region closest to and furthest away from the genital orifice, respectively. New abbreviations are introduced for the vaginal stimulator pilaster (vsp) and vaginal pouch (vpo), but all others are as defined by Solem (1983) and Sutcharit \& Panha (2006):

ag $\quad=$ albumen gland

ap $=$ appendix 


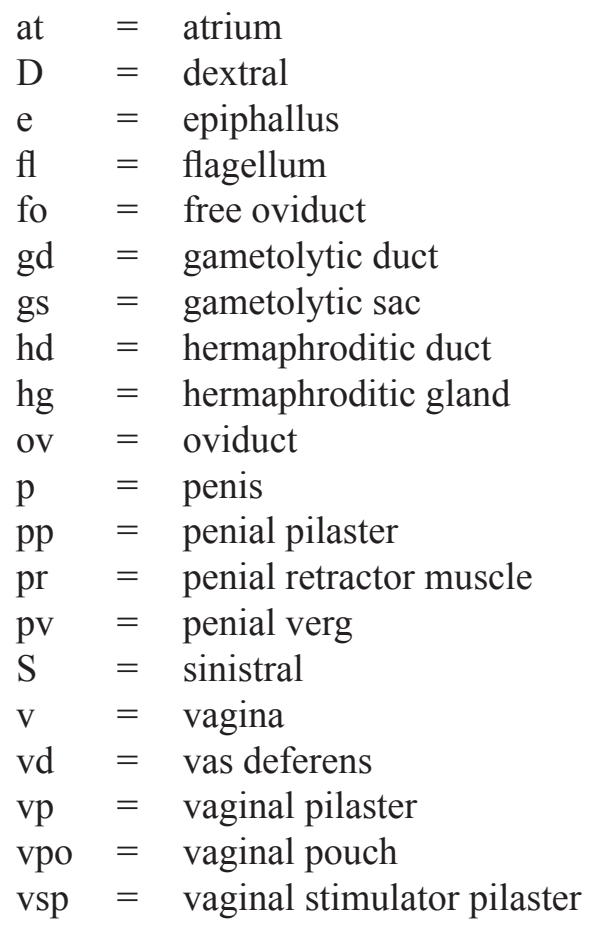

\section{Institutional abbreviations}

ANSP = Academy of Natural Science of Philadelphia, Drexel University, Philadelphia

CUMZ = Chulalongkorn University Museum of Zoology, Bangkok

MNHN = Muséum national d'Histoire naturelle, Paris

NHMUK $=$ Natural History Museum, London

RBINS = Royal Belgian Institute of Natural Sciences, Brussels

RMNH = Naturalis Biodiversity Center, Rijksmuseum van Natuurlijke Historie, Leiden

SMF $=$ Forschungsinstitut und Naturmuseum Senckenberg, Frankfurt am Main

$\mathrm{ZMB} \quad=$ Museum für Naturkunde, Berlin

\section{Results}

Family Camaenidae Pilsbry, 1895

Genus Amphidromus Albers, 1850

Subgenus Amphidromus Albers, 1850

Amphidromus Albers, 1850: 138.

Amphidromus - Martens 1860: 184. — Fulton 1896: 66, 94.

\section{Type species}

Helix perversus Linnaeus, 1758 by subsequent designation of E. von Martens in Albers (1860).

Amphidromus (Amphidromus) roseolabiatus Fulton, 1896

Figs 1, 2A-B, 3A-B, 4A-F, 6A-B, 7A-C; Table 1

Amphidromus roseolabiatus Fulton, 1896: 89, pl. 6, fig. 8. Type locality: Siam [Thailand].

Amphidromus roseolabiatus - Pilsbry 1900: 188, pl. 60, fig. 36. — Laidlaw \& Solem 1961: 527. — Richardson 1985: 42. - Schileyko 2011: 57. — Sutcharit et al. 2015: 88, fig. 13j-k. 
Table 1 (continued on next page). Shell measurements of nine species of Amphidromus from Laos. Specimen catalogue numbers are indicated in parentheses.

\begin{tabular}{|c|c|c|c|c|c|}
\hline \multirow[b]{2}{*}{ Species, locality and CUMZ nos } & \multirow{2}{*}{$\begin{array}{c}\text { No. of } \\
\text { specimens }\end{array}$} & \multicolumn{3}{|c|}{ Range, mean \pm S.D. in $\mathbf{m m}$ of } & \multirow{2}{*}{$\begin{array}{c}\text { Number } \\
\text { of } \\
\text { whorls }\end{array}$} \\
\hline & & $\begin{array}{c}\text { Shell } \\
\text { height }\end{array}$ & $\begin{array}{l}\text { Shell } \\
\text { width }\end{array}$ & $\begin{array}{l}\mathrm{H} / \mathrm{W} \\
\text { ratio }\end{array}$ & \\
\hline \multicolumn{6}{|l|}{ Amphidromus roseolabiatus Fulton, 1896} \\
\hline Ban Pha Vong, Khammouan $(7011,7012)$ & 21 & $\begin{array}{l}28.0-41.6 \\
35.7 \pm 3.24\end{array}$ & $\begin{array}{l}14.6-21.2 \\
17.9 \pm 1.74\end{array}$ & $\begin{array}{c}1.8-2.2 \\
1.9 \pm 0.09\end{array}$ & $6-61 / 2$ \\
\hline Km 70 Lao-Vietnam border, Khammouan (7008) & 4 & $\begin{array}{l}28.0-35.3 \\
33.4 \pm 3.57\end{array}$ & $\begin{array}{l}15.5-19.0 \\
17.1 \pm 1.48\end{array}$ & $\begin{array}{c}1.4-2.2 \\
1.9 \pm 0.34\end{array}$ & $6-61 / 2$ \\
\hline Tam Narng Lod, Khammouan (7009) & 5 & $\begin{array}{l}33.6-40.1 \\
36.8 \pm 3.17\end{array}$ & $\begin{array}{l}16.7-19.1 \\
17.9 \pm 1.03\end{array}$ & $\begin{array}{c}1.9-2.2 \\
2.0 \pm 0.10\end{array}$ & $6-61 / 2$ \\
\hline Tam Mung Korn, Bolikhamxay $(7004,7005)$ & 22 & $\begin{array}{l}28.2-40.0 \\
37.2 \pm 2.40\end{array}$ & $\begin{array}{l}14.1-21.7 \\
20.2 \pm 1.52\end{array}$ & $\begin{array}{c}1.7-2.0 \\
1.8 \pm 0.10\end{array}$ & $6-61 / 2$ \\
\hline Thad Khaungsy, Luang Phrabang $(7013,7047,7048)$ & 6 & $\begin{array}{l}34.3-41.8 \\
37.5 \pm 2.71\end{array}$ & $\begin{array}{l}17.8-19.8 \\
18.8 \pm 0.87\end{array}$ & $\begin{array}{c}1.9-2.1 \\
1.9 \pm 0.07\end{array}$ & $6-61 / 2$ \\
\hline Nam Turn Bridge, Khmakert $(7006,707)$ & 9 & $\begin{array}{l}26.1-34.2 \\
30.3 \pm 2.31\end{array}$ & $\begin{array}{l}15.2-17.5 \\
16.3 \pm 0.75\end{array}$ & $\begin{array}{c}1.6-2.0 \\
1.8 \pm 0.14\end{array}$ & $6-61 / 2$ \\
\hline Ban Phone Can, Yommalat, Khammouan (7001) & 8 & $\begin{array}{l}27.2-33.8 \\
30.4 \pm 2.39\end{array}$ & $\begin{array}{l}13.4-15.9 \\
14.1 \pm 0.91\end{array}$ & $\begin{array}{c}1.9-2.3 \\
2.1 \pm 0.11\end{array}$ & $6-61 / 2$ \\
\hline Wat Paphar, Khamkert (7002) & 6 & $\begin{array}{l}25.6-34.4 \\
30.7 \pm 3.11\end{array}$ & $\begin{array}{l}12.8-17.3 \\
15.5 \pm 1.59\end{array}$ & $\begin{array}{c}1.8-2.0 \\
1.9 \pm 0.07\end{array}$ & $6-61 / 2$ \\
\hline Limestone Quarry, Bolikhamxay (4013) & 6 & $\begin{array}{l}26.9-40.7 \\
30.2 \pm 5.25\end{array}$ & $\begin{array}{l}13.3-19.3 \\
15.4 \pm 2.08\end{array}$ & $\begin{array}{c}1.8-2.1 \\
1.9 \pm 0.12\end{array}$ & $6-61 / 2$ \\
\hline Ban Phahom, Vang Vieng $(4017,7049)$ & 31 & $\begin{array}{l}23.6-30.4 \\
27.4 \pm 1.97 \\
\end{array}$ & $\begin{array}{c}12.9-16.5 \\
14.6 \pm 0.8 \\
\end{array}$ & $\begin{array}{c}1.6-2.1 \\
1.8 \pm 0.12 \\
\end{array}$ & $6-61 / 2$ \\
\hline \multicolumn{6}{|l|}{ Amphidromus givenchyi Geret, 1912} \\
\hline Thad Lor, Salavan $(7015,7016)$ & 110 & $\begin{array}{c}23.3-43.6 \\
36.5 \pm 3.7\end{array}$ & $\begin{array}{l}11.8-22.9 \\
19.6 \pm 2.26\end{array}$ & $\begin{array}{c}1.7-2.1 \\
1.8 \pm 0.09\end{array}$ & 7 \\
\hline Wat Phou, Salavan $(7017,7018)$ & 44 & $\begin{array}{l}27.1-37.8 \\
33.1 \pm 2.44\end{array}$ & $\begin{array}{l}15.6-21.2 \\
18.1 \pm 1.35\end{array}$ & $\begin{array}{c}1.6-2.1 \\
1.8 \pm 0.08\end{array}$ & $6-61 / 2$ \\
\hline \multicolumn{6}{|l|}{ Amphidromus syndromoideus sp. nov. } \\
\hline Tam Narng Ann, Khammouan $(7019,7020,7021)$ & 20 & $\begin{array}{l}21.8-29.1 \\
25.9 \pm 1.69 \\
\end{array}$ & $\begin{array}{l}11.2-14.2 \\
12.7 \pm 0.66 \\
\end{array}$ & $\begin{array}{c}1.7-2.2 \\
2.0 \pm 0.10 \\
\end{array}$ & 6 \\
\hline \multicolumn{6}{|l|}{ Amphidromus pervariabilis Bavay \& Dautzenberg, 1909} \\
\hline Ban Namly, Phongsaly (7014) & 3 & $\begin{array}{l}31.5-40.9 \\
37.2 \pm 5.02\end{array}$ & $\begin{array}{l}18.6-19.6 \\
19.0 \pm 0.54\end{array}$ & $\begin{array}{c}1.6-2.2 \\
1.9 \pm 0.31\end{array}$ & $71 / 2$ \\
\hline \multicolumn{6}{|l|}{ Amphidromus areolatus (Pfeiffer, 1861) } \\
\hline Thad Fek, Attapeu $(7022,7023)$ & 33 & $\begin{array}{l}13.3-21.8 \\
16.9 \pm 2.19\end{array}$ & $\begin{array}{l}7.1-10.2 \\
8.5 \pm 0.74\end{array}$ & $\begin{array}{c}1.5-2.2 \\
1.9 \pm 0.13\end{array}$ & $61 / 2$ \\
\hline Thad Phasoam, Champasak (7024) & 9 & $\begin{array}{l}13.8-21.8 \\
16.5 \pm 2.66\end{array}$ & $\begin{array}{l}6.9-10.5 \\
8.4 \pm 1.08\end{array}$ & $\begin{array}{c}1.8-2.0 \\
1.9 \pm 0.08\end{array}$ & $61 / 2$ \\
\hline \multicolumn{6}{|l|}{ Amphidromus flavus (Pfeiffer, 1861) } \\
\hline Wat Phousy, Luang Phrabang (7025) & 33 & $\begin{array}{l}23.2-37.4 \\
28.4 \pm 3.67\end{array}$ & $\begin{array}{l}11.8-17.4 \\
14.4 \pm 1.26\end{array}$ & $\begin{array}{c}1.7-2.1 \\
1.9 \pm 0.11\end{array}$ & $61 / 2$ \\
\hline Ban Na Deauy, Luang Phrabang $(7026,7027)$ & 11 & $\begin{array}{l}22.2-29.8 \\
25.7 \pm 2.27\end{array}$ & $\begin{array}{l}12.1-14.2 \\
12.9 \pm 0.68\end{array}$ & $\begin{array}{c}1.8-2.3 \\
1.9 \pm 0.17\end{array}$ & $61 / 2$ \\
\hline Mouhot's Tomb, Luang Phrabang (7028) & 5 & $\begin{array}{l}24.4-29.0 \\
27.6 \pm 1.88\end{array}$ & $\begin{array}{l}13.1-13.9 \\
13.5 \pm 0.36\end{array}$ & $\begin{array}{c}1.7-2.2 \\
2.0 \pm 0.17\end{array}$ & $61 / 2$ \\
\hline Tam Pou Kham, Vang Vieng (7029) & 12 & $\begin{array}{l}23.7-35.5 \\
28.3 \pm 3.48\end{array}$ & $\begin{array}{l}13.0-17.1 \\
14.3 \pm 1.35\end{array}$ & $\begin{array}{c}1.7-2.2 \\
1.9 \pm 0.14\end{array}$ & $61 / 2$ \\
\hline
\end{tabular}


INKHAVILAY K. et al., Review and new species of Amphidromus in Laos

\begin{tabular}{|c|c|c|c|c|}
\hline \multicolumn{5}{|l|}{ Amphidromus xiengensis Morlet, 1891} \\
\hline Ban Phon Pai, Champasak (7030) & 33 & $\begin{array}{ll}21.4-36.2 & 13.4-16.9 \\
31.0 \pm 3.04 & 15.1 \pm 0.96\end{array}$ & $\begin{array}{c}1.4-2.3 \\
2.0 \pm 0.14\end{array}$ & $61 / 2-7$ \\
\hline Ban Oudom limestone, Oudomxay (7032) & 6 & $\begin{array}{ll}22.1-29.7 & 11.2-13.9 \\
26.5 \pm 2.61 & 13.0 \pm 0.94\end{array}$ & $\begin{array}{c}1.9-2.1 \\
2.0 \pm 0.08\end{array}$ & $61 / 2-7$ \\
\hline Mouhot's Tomb, Luang Phrabang (7033) & 5 & $\begin{array}{ll}21.9-35.2 & 12.0-14.8 \\
28.1 \pm 5.03 & 13.2 \pm 1.43\end{array}$ & $\begin{array}{c}1.8-2.3 \\
2.1 \pm 0.21\end{array}$ & $61 / 2-7$ \\
\hline Thad Phasoam, Boloven Plateau, Champasak (7031) & 10 & $\begin{array}{cc}17.4-34.4 & 8.7-15.9 \\
29.9 \pm 5.87 & 13.8 \pm 2.46\end{array}$ & $\begin{array}{c}2.0-2.2 \\
2.1 \pm 0.07\end{array}$ & $6^{1 / 2}-7$ \\
\hline Ban Na Deauy, Luang Phrabang $(7036,7037)$ & 4 & $\begin{array}{ll}22.4-29.4 & 11.4-13.9 \\
26.7 \pm 3.32 & 13.1 \pm 1.16 \\
\end{array}$ & $\begin{array}{c}1.8-2.1 \\
2.0 \pm 0.15\end{array}$ & $61 / 2-7$ \\
\hline \multicolumn{5}{|l|}{ Amphidromus fuscolabris Möllendorff, 1898} \\
\hline Ban Phone, Sekong $(7040,7041,7042,7043)$ & 112 & $\begin{array}{ll}26.0-43.5 & 13.1-18.1 \\
34.3 \pm 3.56 & 15.2 \pm 1.04\end{array}$ & $\begin{array}{c}1.8-2.6 \\
2.2 \pm 0.13\end{array}$ & 7 \\
\hline Ban Xai Na Pho, Champasak (7044) & 3 & $\begin{array}{ll}26.0-43.6 & 13.1-18.1 \\
34.8 \pm 4.06 & 15.3 \pm 1.20\end{array}$ & $\begin{array}{c}1.8-2.5 \\
2.2 \pm 0.14\end{array}$ & 7 \\
\hline \multicolumn{5}{|l|}{ Amphidromus xiengkhaungensis sp. nov. } \\
\hline Nong Tang, Xieng Khaung $(7045,7046)$ & 4 & $\begin{array}{ll}21.4-29.8 & 14.8-17.0 \\
25.6 \pm 3.49 & 15.7 \pm 1.04\end{array}$ & $\begin{array}{c}1.4-1.7 \\
1.6 \pm 0.13\end{array}$ & 6 \\
\hline
\end{tabular}

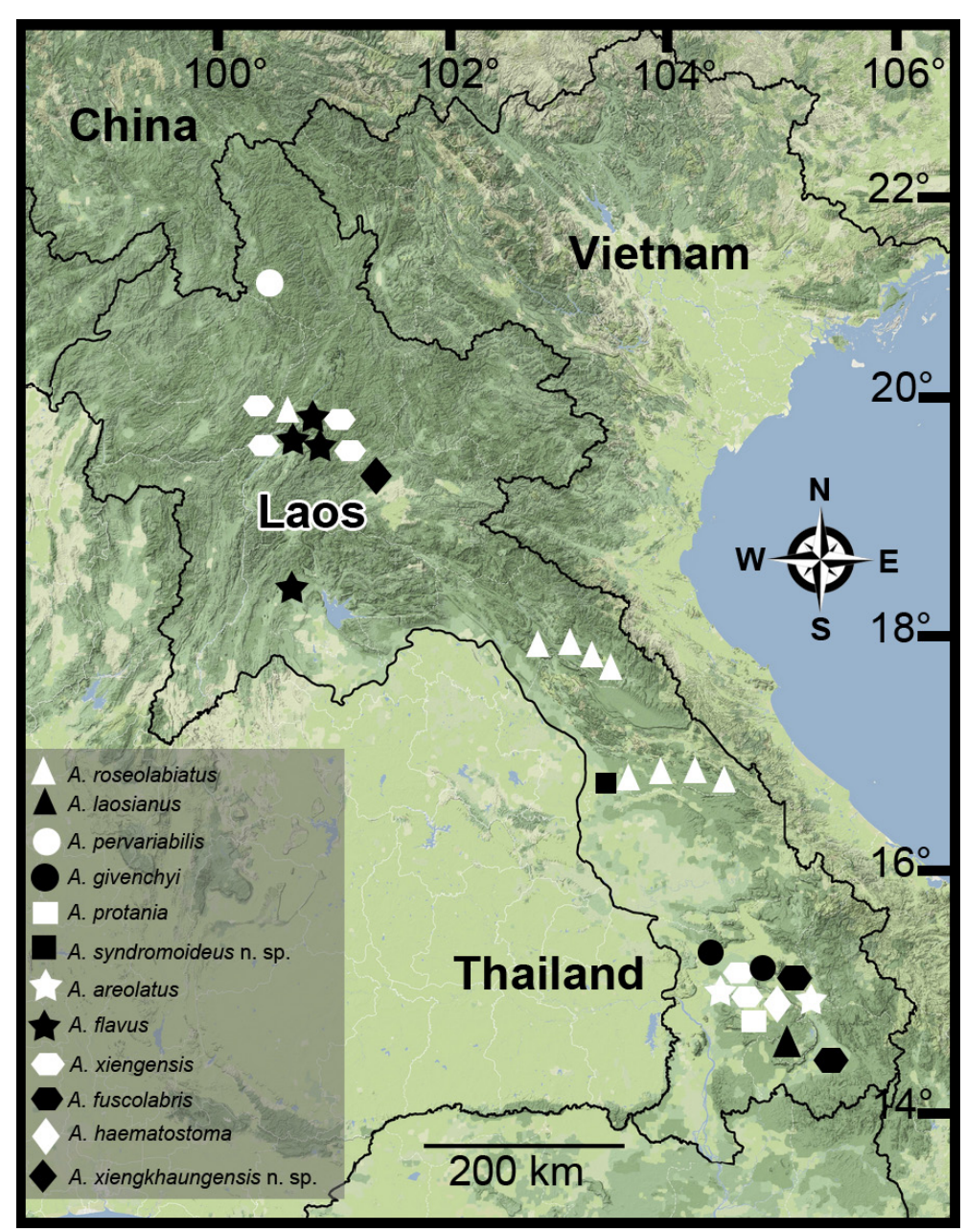

Fig. 1. Distribution map of Amphidromus spp. in Laos recognized in this study. 


\section{Material examined}

Type material

THAILAND: Lectotype, NHMUK 19601462 (Sutcharit et al. 2015: fig. 13j); paralectotype, NHMUK 19601463 (1S shell, Sutcharit et al. 2015: fig. 13k).

\section{Other material}

LAOS: 5D + 3S shells, Ban Phone Can, Yommalat District, Khammouan (CUMZ 7001); 5D + 1S shells, Wat Paphar, Khamkert District, Bolikhamxay (CUMZ 7002); 2D + 1S shells, Thad Mouang, Khamkert District, Bolikhamxay (CUMZ 7003); 4D + 10S specimens, in ethanol (Fig. 4E-F, CUMZ 7004), 13S specimens in freezer (Fig. 2B, CUMZ 7005), Tam Mung Korn, Khamkert District, Bolikhamxay; 1D + 1S specimens, in ethanol (Fig. 4C-D, CUMZ 7006), 4D + 5S specimens in freezer (Fig. 3A-B, CUMZ 7007), Nam Turn Bridge, Khamkert District, Bolikhamxay; 8D + 6S shells, Limestone quarry, Bolikhamxay (CUMZ 4013); 4D + 3S shells, pink aperture, Km. 70 on the road from Laos to Vietnam border, Yommalat District, Khammouan (CUMZ 7008); 8D shells, pink aperture, Tam Narng Lod, Yommalat District, Khammouan (CUMZ 7009); 3D + 1S shells, pink aperture, Hauy In River, Yommalat District, Khammouan (CUMZ 7010); 12D + 8S specimens, in ethanol, pink aperture (Fig. 4A-B, CUMZ 7011), 5D specimens, in ethanol (Figs 2A, 6A-B, 7A-C, CUMZ 7012), Ban Pha Vong, Yommalat District, Khammouan; 1D + 1S shells, pink aperture (CUMZ 7013), 6D specimens, in ethanol (CUMZ 7047), 4D specimens, in ethanol (CUMZ 7048), 1D + 1S shells, pink aperture (CUMZ 7035), Thad Khaungsy Waterfall, Luang Phrabang District, Luang Phrabang; 6D shells (CUMZ 40107), 10S + 21D shells (CUMZ 7049), Ban Phahom, Vang Vieng District, Vientiane.
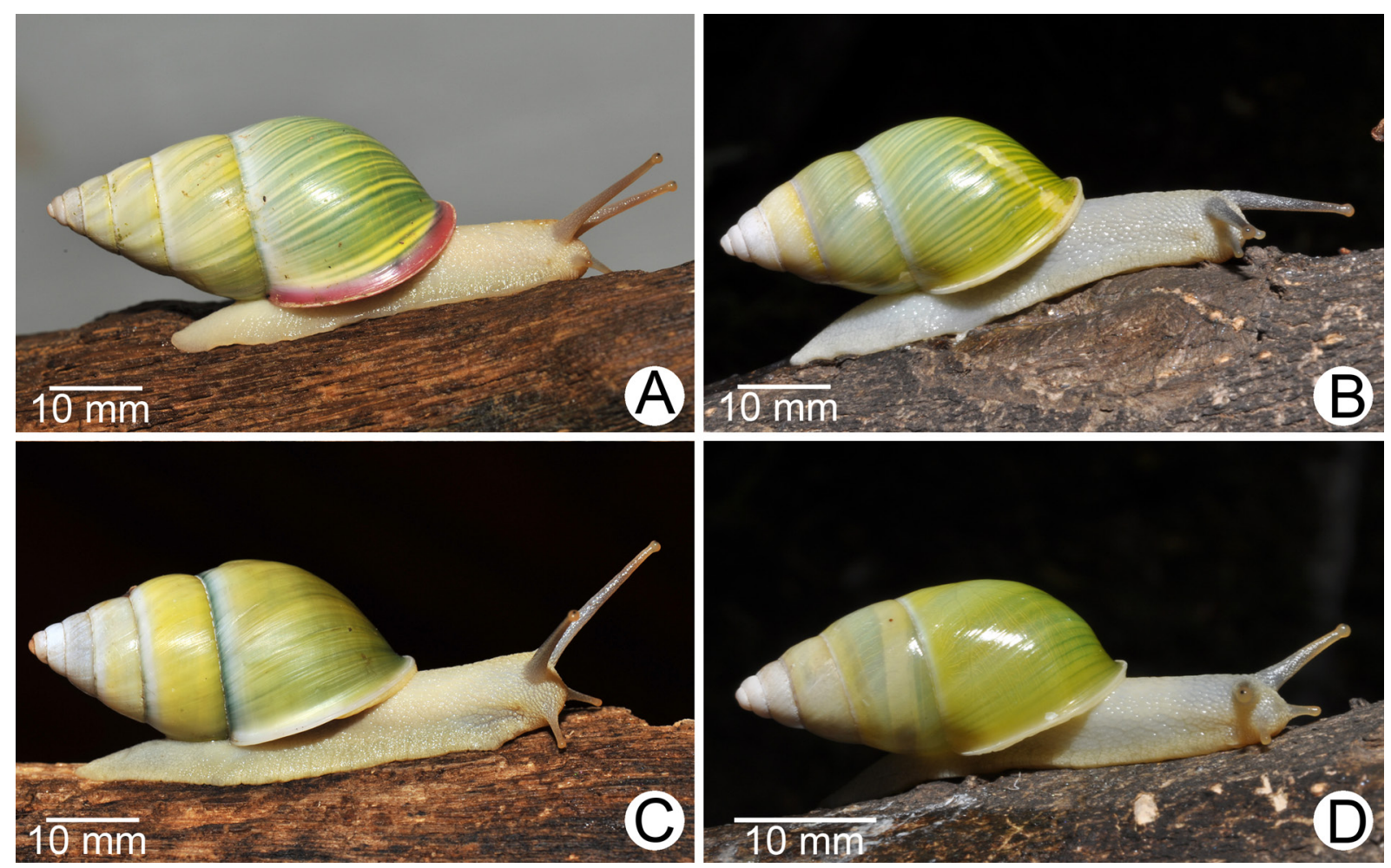

Fig. 2. Living snails. A-B. Amphidromus roseolabiatus Fulton, 1896. A. Typical form from Ban Phavong, Khammouan, Laos (CUMZ 7012). B. Form with white lip from Tam Mung Korn, Bolikhamxay, Laos (CUMZ 7005). C. Amphidromus givenchyi Geret, 1912 from Thad Lor Waterfall, Salavan, Laos (CUMZ 7018). D. Amphidromus syndromoideus sp. nov., holotype from the type locality (CUMZ 7019). 

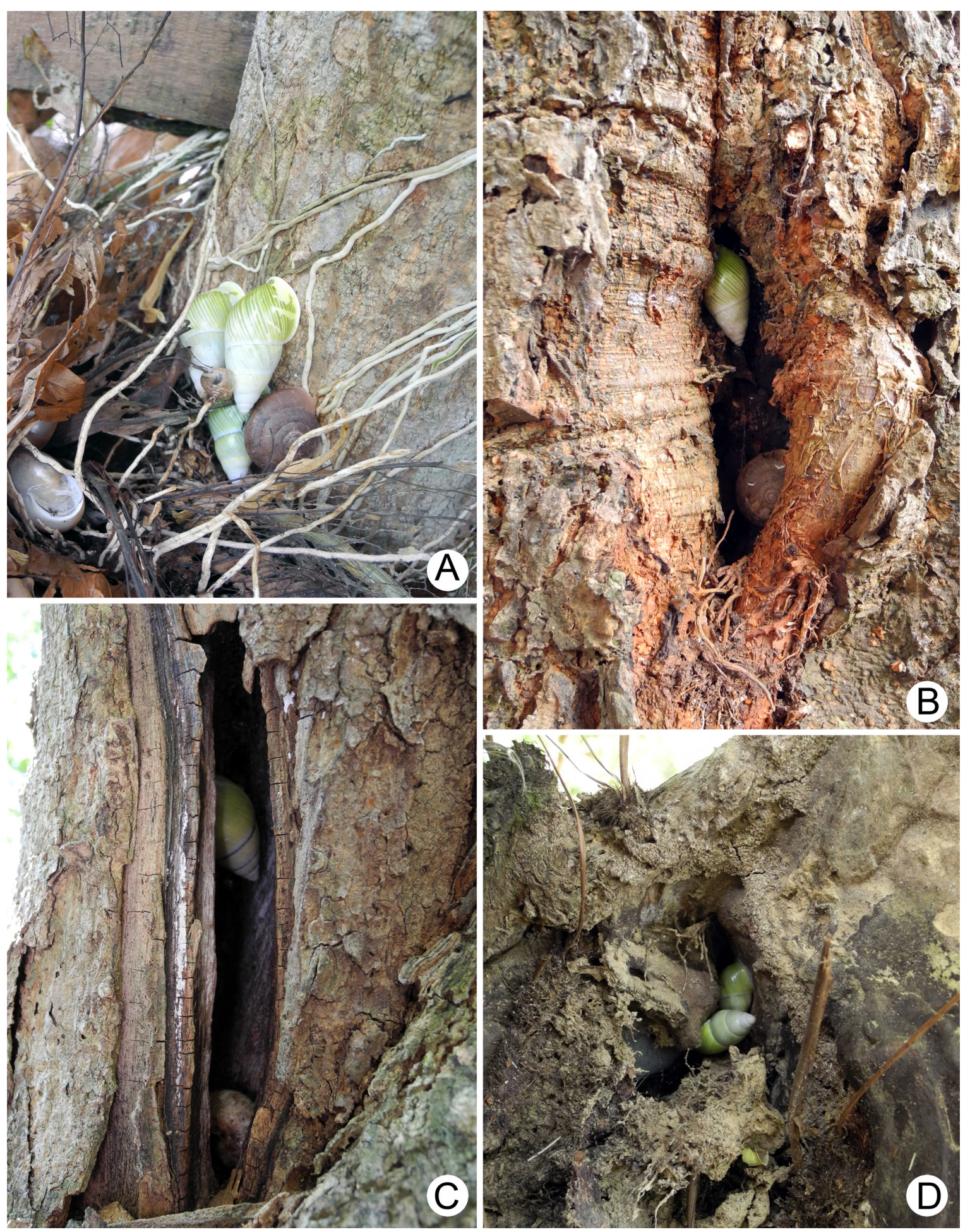

Fig. 3. Aestivation sites of Amphidromus species. A-B. Amphidromus roseolabiatus Fulton, 1896 (shell height about $34 \mathrm{~mm}$ ) from NamTurn Bridge, Bolikhamxay, Laos, aestivated. A. Inside sterile fronds of stag horn ferns, Platycerium Desv. B. In a small hole on a Jackfruit tree trunk, Artocarpus heterophyllus Lam., with other snails, Quantula Baker, 1941 and Durgella Blanford, 1863. C. Amphidromus givenchyi Geret, 1912 (shell height about $43 \mathrm{~mm}$ ), hiding in a small hole of a dipterocarpus tree shell. D. Amphidromus syndromoideus sp. nov. (shell height about $28 \mathrm{~mm}$ ) from the type locality, hiding in a hole of a tree, visible after removal of clusters of sterile fronds of the basket fern Drynaria (Bory) J. Sm . 


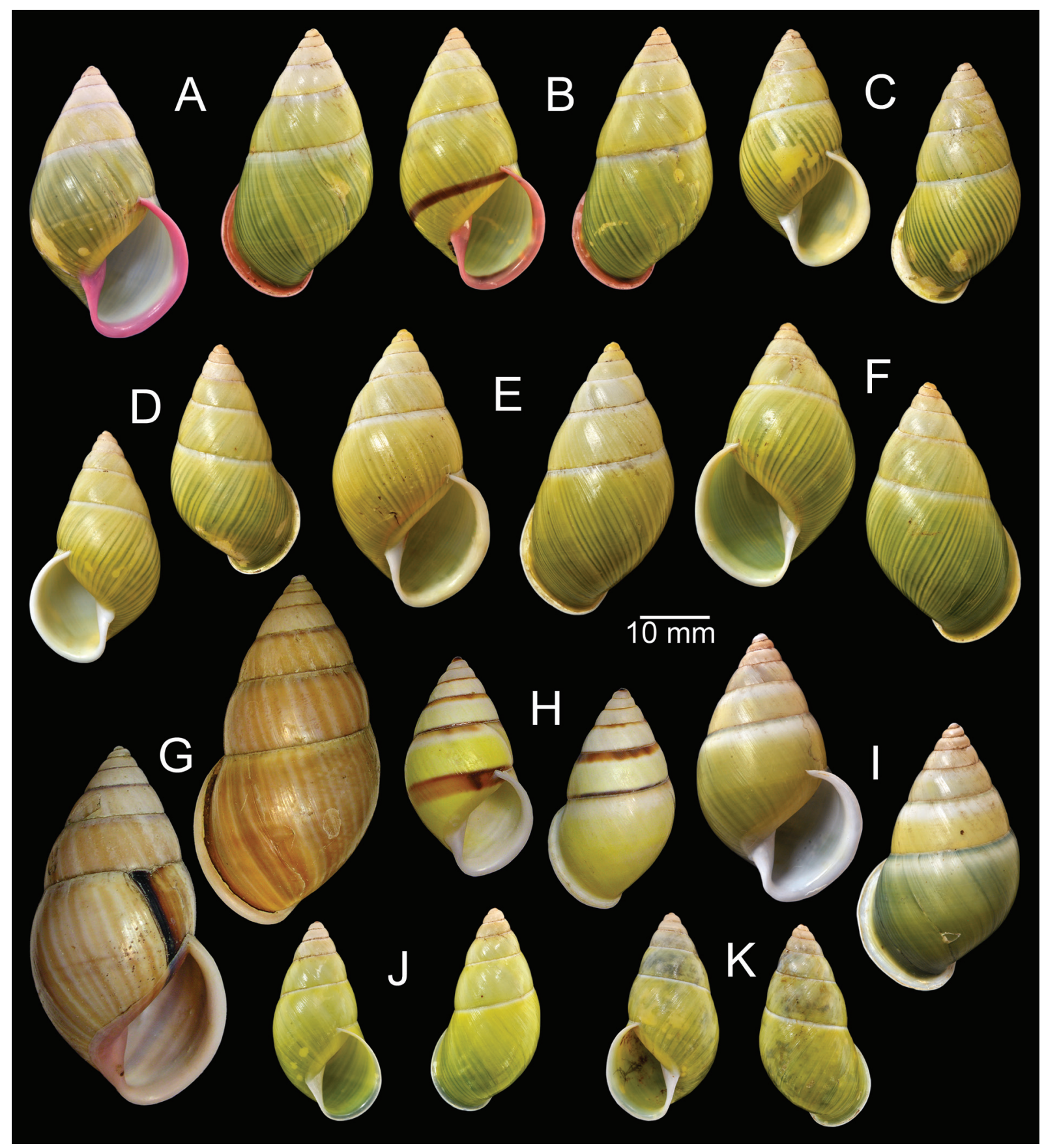

Fig. 4. Shells of Amphidromus (Amphidromus) spp. A-F. Amphidromus roseolabiatus Fulton, 1896. A-B. Typical form from Ban Phavong, Khammouan, Laos (CUMZ 7011). C-D. Form with white lip from Nam Turn Bridge, Bolikhamxay, Laos (CUMZ 7006). E-F. Form with white lip from Tam Mung Korn, Bolikhamxay, Laos (CUMZ 7004). G. Amphidromus laosianus Bavay, 1898 from Khone, Champasak, Laos (RMNH 101049). H. Amphidromus protania Lehmann \& Maassen, 2004, holotype (RMNH 98143). I. Amphidromus givenchyi Geret, 1912 from Thad Lor Waterfall, Salavan, Laos (CUMZ 7015). J-K. Amphidromus syndromoideus sp. nov. from the type locality. J. Holotype (CUMZ 7019). K. Paratype (CUMZ 7020). 
VIETNAM: 2D+3S shells, Phong Nha National Park (CUMZ 7053).

THAILAND: 1D shell, Nan Province, Thailand (CUMZ 7054).

\section{Description}

Shell chirally dimorphic, elongate to ovate conical, rather thin and glossy. Spire conical; apex acute, light brown and without black spot on tip. Whorls 6 to 7 nearly smooth; suture wide and depressed; last whorl rounded. Periostracum usually deciduous to yellowish-green radial streaks, more conspicuous on last whorl and faded in previous whorls. Last whorl processes thin, whitish subsutural band, sometimes with one or two reddish-brown spiral bands below periphery but usually not reaching lip; varix absent. Parietal callus thin and transparent. Aperture ovate to elongate; peristome expanded and not reflected; lip usually purplish-pink or white. Columella straight, thickened, purplish-pink or white. Umbilicus narrowly opened.

\section{Radula}

Each row contains about 130 (66-(10-6)-1-(6-10)-63) teeth. Central tooth unicuspid and spatulate with curved cusp. Lateral teeth bicuspid. Endocone cylindrical, slightly oblique, with wide notch; ectocone large, with truncated to rounded cusp. Marginal teeth tricuspid, start around tooth number 6 to 10; endocone small; mesocone large, with rounded cusp, ectocone small, with sharp cusp. Outermost teeth with small and sharp cusp on endocone and extocone; mesocone large, with curved cusps (Fig. 7A-C).

\section{Genital organs}

Atrium (at) rather short $(\mathrm{n}=10)$. Penis $(\mathrm{p})$ long and stout. Epiphallus (e) long, about two times as long as penis; flagellum (fl) longer than epiphallus and terminated in folded coil. Appendix very small, extends from folded coil of flagellum, about same length as epiphallus. Penial retractor muscle (pr) short, thickened and inserted distally on penis. Vas deferens (vd) narrow tube connecting epiphallus and free oviduct (Fig. 6A).

Internal penial wall corrugated into series of thick penial pilasters (pp), which form a fringe around penial verge. Penial verge (pv) rather long and curved, conical, with smooth surface and orifice located at tip (Fig. 6B).

Vagina cylindrical, about two times as long as penis. Gametolytic duct very long, proximal to genital orifice large, coiled; distal to genital orifice tapering to small tube, short, about one-third length of proximal part and connected to enlarged gametolytic sac. Oviduct and albumin gland small (Fig. 6A).

Internally, vaginal wall performs longitudinal vaginal pilasters (vp); proximal to genital orifice with small corrugated continuous ridges, ridges distally becoming smooth (Fig. 6B).

\section{Distribution}

This species is distributed widely, from many localities in central and northern Laos. There are also records from Nan Province, Thailand and Phong Nha National Park, Vietnam.

\section{Remarks}

Amphidromus roseolabiatus differs from A. smithi Fulton, 1896 and A. ventrosulus Möllendorff, 1900 (Zilch 1953; Sutcharit et al. 2015) in having an enantiomorphic shell coiling, purplish-pink lip and fine green streaks. In contrast, $A$. smithi has a sinistral shell, brownish lip with dark spot on the apex, and A. ventrosulus has a sinistral shell, uniform green color, elongate spire and more depressed suture. 
Laidlaw \& Solem (1961) recognized A. roseolabiatus as belonging to an uncertain subgenus that was probably close to the subgenus Syndromus. However, this species exhibits dimorphic shell coiling with a long flagellum and appendix, which are typical characters of the nominotypical subgenus (Fig. 6A). Two color forms were observed in the recently collected materials. The typical color form has a greenish radial streaked periostracum and pinkish apertural lip (Figs 2A, 4A-B). There are some specimens with the typical color form showing one or two additional reddish-brown lower, peripheral bands (Fig. 4B). The second, whitish form usually has a greenish periostracum, as in the typical color form, but a white apertural lip (Figs 2B, 4C-F). However, these two color forms have identical genital structures and sculptures inside the penis and vagina.

Amphidromus (Amphidromus) laosianus Bavay, 1898

Figs 1, 4G

Amphidromus laosianus Bavay, 1898: 15, 16, pl. 2, fig. 1, 1a. Type locality: Khône, sur les bords du Mékong [on the banks of the Mekong River, Khone, Champasak, Laos].

Amphidromus laosianus var. albocaerulescens Bavay, 1898: 16, pl. 2, fig. 2, 2a. Type locality: Khône, sur les bords du Mékong [on the banks of the Mekong River, Khone, Champasak, Laos].

Amphidromus laosianus - Pilsbry 1900: 183, 184, pl. 62, figs 60-61. — Laidlaw \& Solem 1961: $526,634$.

Amphidromus laosianus var. albocaerulescens - Pilsbry 1900: 184, pl. 62, figs 62-63. — Laidlaw \& Solem 1961: 526, 598.

\section{Material examined}

LAOS: 1D + 1S shells (Fig. 4G), Khone District, Champasak, South Laos (RMNH 101049); 1D + 2S shells, W.J.M. Maassen collection; 2D + 2D juveniles, Khone, South Laos, ZMB, Lehmann collection.

\section{Remarks}

Currently known only from the type locality. The unique shell characters are chirally dimorphic, conical to elongate conical; whorls weakly convex, with white subsutural band. Shell color with yellowishbrown or brownish radial streaks on pinkish to whitish ground color; dark varix present. Aperture elongated; peristome thickened, expanded and reflected; lip folded and pinkish. Parietal callus pinkish and thickened; columella pinkish and straight; umbilicus imperforated.

Laidlaw \& Solem (1961) mentioned that this species is similar to the A. atricallosus leucoxanthus variety "laidlawi" (Solem 1965: pl. 1, fig. 3; Sutcharit \& Panha 2006: fig. 4d-e). However, it differs in having a slender shell and pinkish peristome, parietal callus and inside of the aperture, while "var. laidlawi" has a white lip, parietal callus and inside aperture, and more depressed suture. Furthermore, $A$. cambojiensis (Reeve, 1860) can be distinguished from this species by having a very large and thickened shell, thickened and white parietal callus and lip, and purplish inside aperture (see Sutcharit et al. 2015).

Amphidromus (Amphidromus) pervariabilis Bavay \& Dautzenberg, 1909 Figs 1, 5A-L; Table 1

Amphidromus pervariabilis Bavay \& Dautzenberg, 1909b: 246-247. Type locality: Ban-Lao, MuongKong, Pha-Long, Pac Kha.

Amphidronus pervariabilis - Bavay \& Dautzenberg 1909a: 279-281, pl. 9, figs 1-10, pl. 10, figs 1-8. Laidlaw \& Solem 1961: 527, 528. — Richardson 1985: 15. 


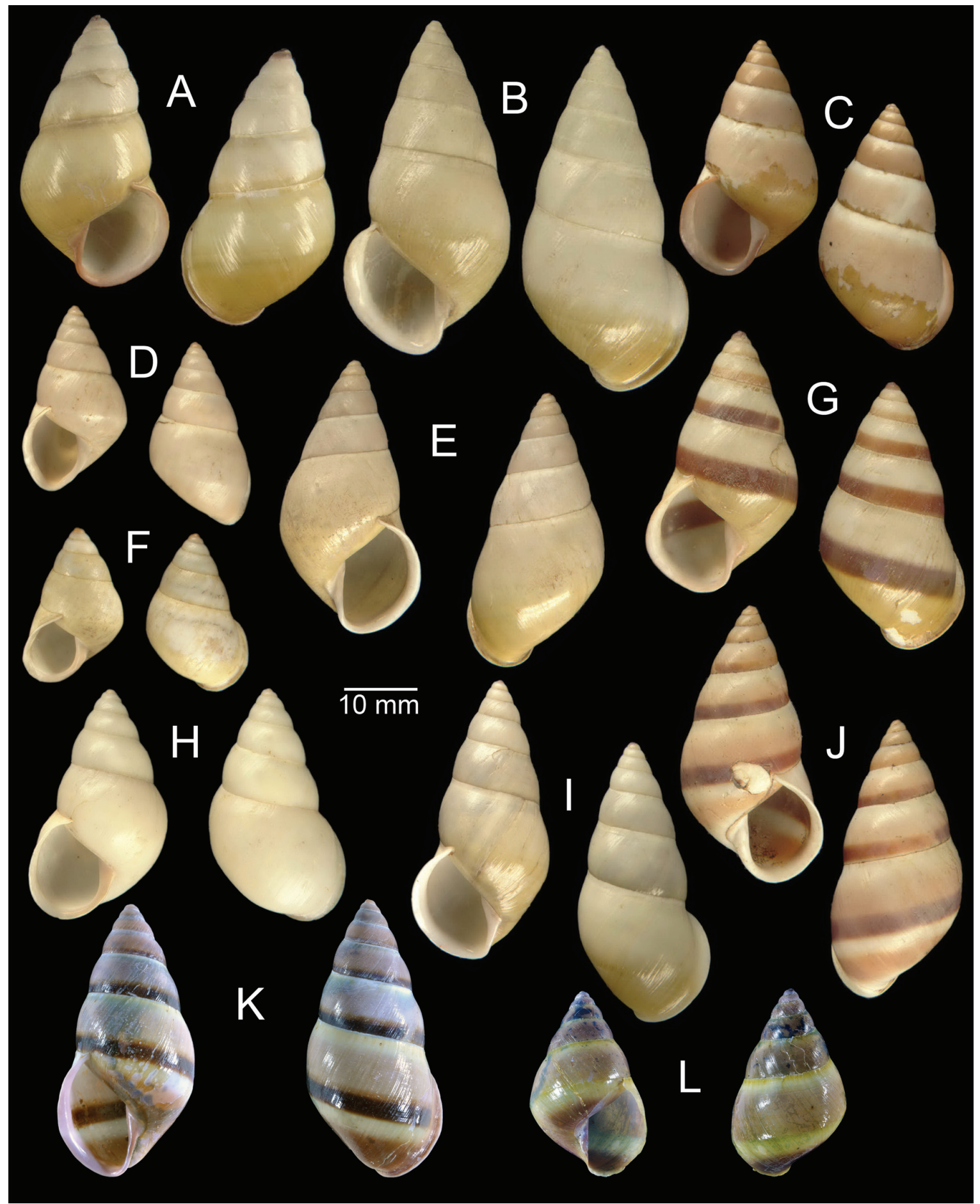

Fig. 5. Shells of Amphidromus pervariabilis Bavay \& Dautzenberg, 1909. A-B. Syntype of the nominotypical form (MNHM-IM-2000-2049). C. Var. "bifasciata" Bavay \& Dautzenberg, 1909, syntype (MNHM-IM-2000-2059). D. Var. "goniostoma" Bavay \& Dautzenberg, 1909, syntype (MNHMIM-2000-2058). E. Var. "lilacina" Bavay \& Dautzenberg, 1909, syntype (MNHM-IM-2000-2052). F. Var. "minor" Bavay \& Dautzenberg, 1909, syntype (MNHM-IM-2000-2050). G. Var. "monozonalis" Bavay \& Dautzenberg, 1909, syntype (MNHM-IM-2000-2057). H. Var. "obesa" Bavay \& Dautzenberg, 1909, syntype (MNHM-IM-2000-2053). I. Var. "protracta" Bavay \& Dautzenberg, 1909, syntype (MNHM-IM-2000-2051). J. Var. "tricolor" Bavay \& Dautzenberg, 1909, syntype (MNHMIM-2000-2054). K-L. Specimens from Khua District, Phongsaly, Laos (CUMZ 7014). 


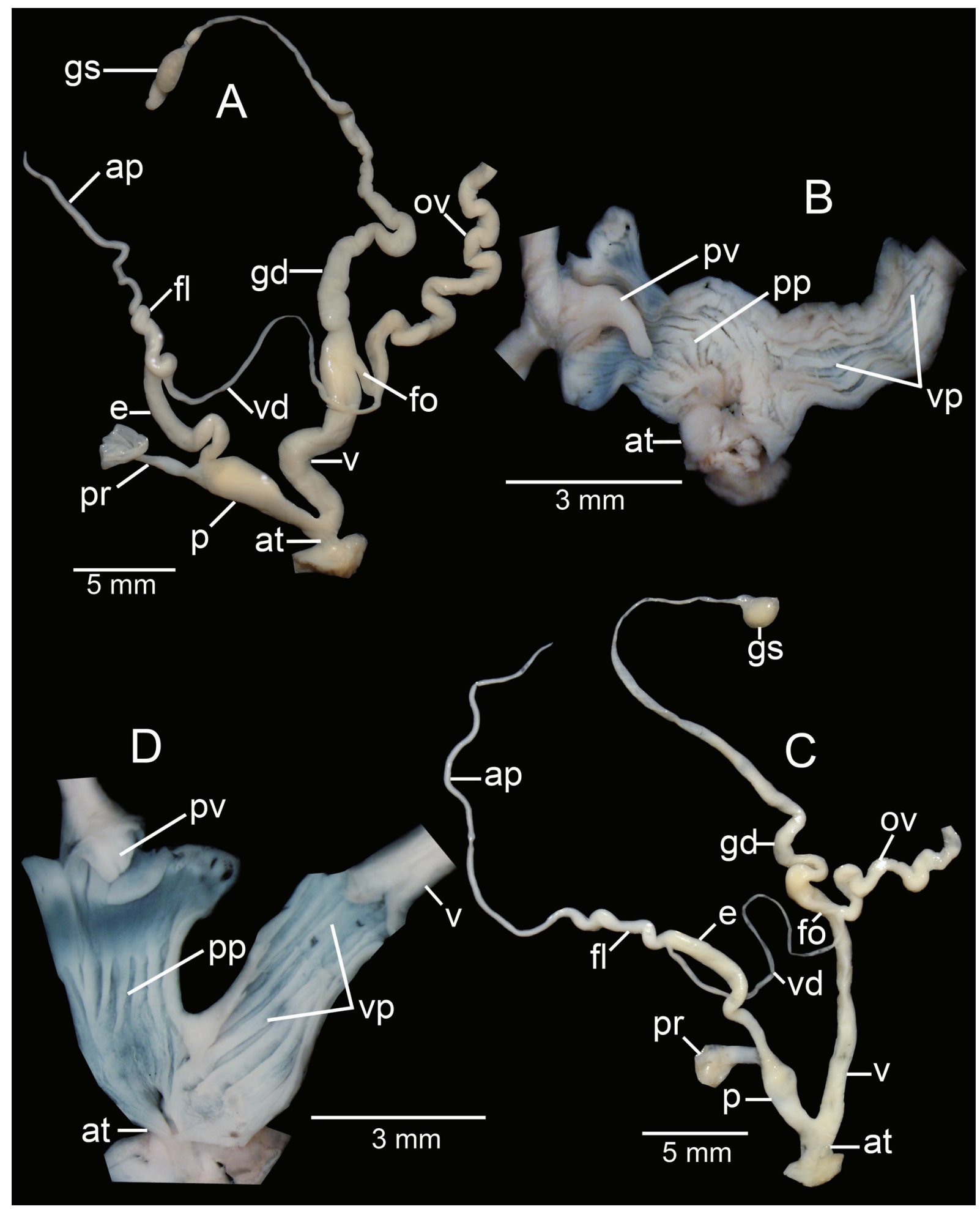

Fig. 6. Genitalia of Amphidromus spp. A-B. Amphidromus roseolabiatus Fulton, 1896 from Ban Phavong, Khammouan, Laos showing reproductive system and interior structures of penis and vaginal chamber (CUMZ 7012). C-D. Amphidromus syndromoideus sp. nov., holotype, showing general characteristics of the genital system and interior structures of penis and vagina chamber (CUMZ 7019). 


\section{Material examined}

\section{Type material}

VIETNAM: 2 shells (Fig. 5A-B), syntypes of A. pervariabilis s.str. MNHM-IM-2000-2049, from Ban-

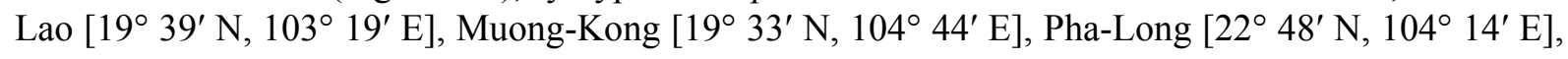
Pac Kha $\left[21^{\circ} 00^{\prime} \mathrm{N}, 104^{\circ} 35^{\prime} \mathrm{E}\right]$.

VIETNAM: 2 shells (Fig. 5C), syntypes of A. pervariabilis var. "bifasciata", from Ban-Lao, MuongKong, Pha-Long, Pac Kha (MNHM-IM-2000-2059).

VIETNAM: 1 shell (Fig. 5D), syntype of A. pervariabilis var. "goniostoma”, from Phong-Tho, $22^{\circ} 34^{\prime} \mathrm{N}$, $103^{\circ} 22^{\prime}$ E (MNHM-IM-2000-2058).
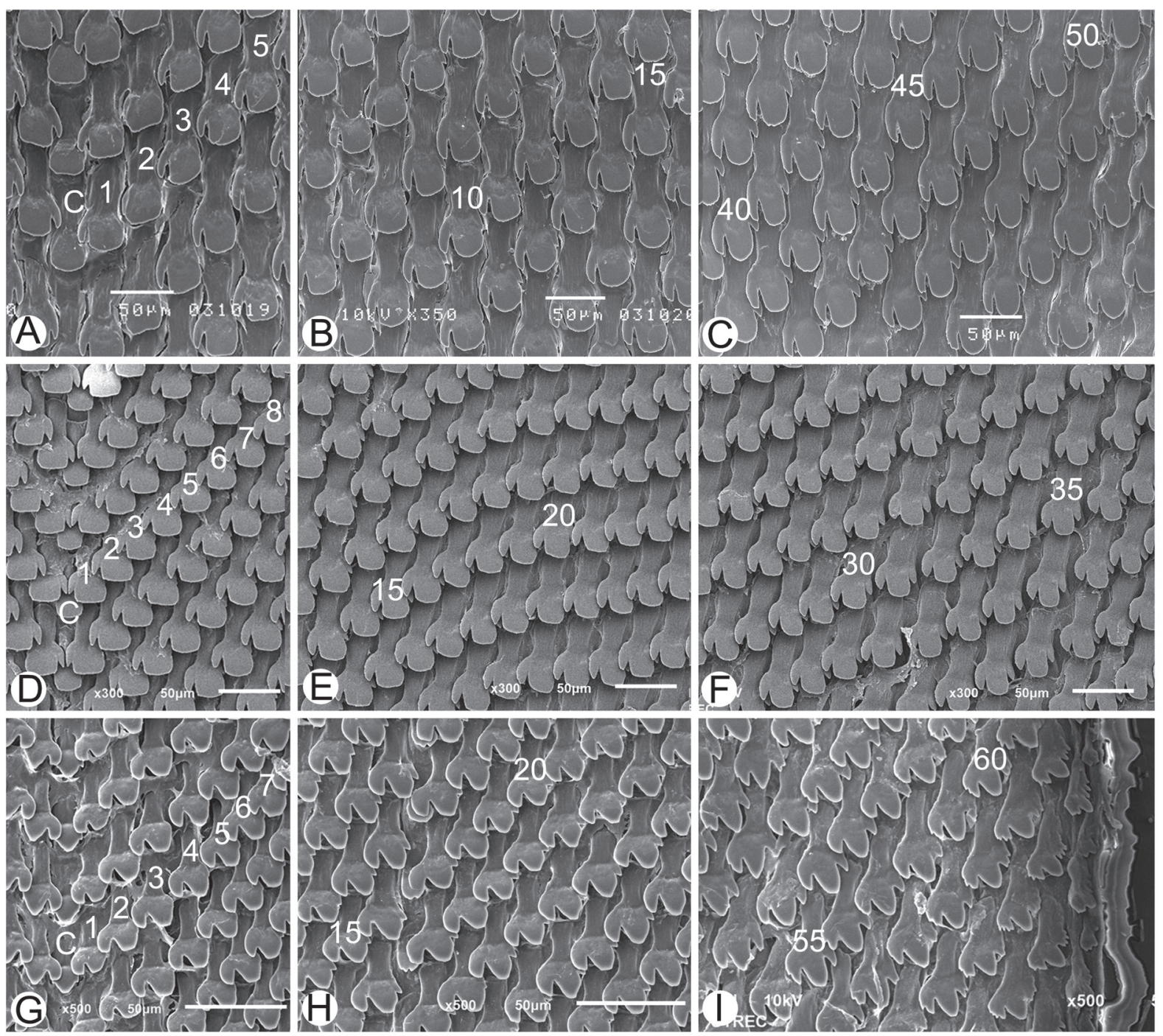

Fig. 7. SEM images of the radula. A-C. Amphidromus roseolabiatus Fulton, 1896 from Ban Phavong, Khammouan, Laos (CUMZ 7012). D-F. Amphidromus syndromoideus sp. nov., holotype (CUMZ 7019). G-I. Amphidromus areolatus (Pfeiffer, 1861) from Thad Fek, Attapue, Laos (CUMZ 7023). A, $\mathrm{D}, \mathrm{G}=$ central tooth with the first to fifth to eighth lateral teeth; B, E, H = lateral teeth with the tricuspid marginal teeth transition; C, F, I = outermost marginal teeth. Numbers indicate the order of the lateral and marginal teeth. Central tooth indicated by ' $\mathrm{C}$ '. 
VIETNAM: 2 shells (Fig. 5E), syntypes of A. pervariabilis var. "lilacina", from Ban-Lao (MNHMIM-2000-2052).

VIETNAM: 1 shell (Fig. 5F), syntype of A. pervariabilis var. "minor", from unknown locality (MNHMIM-2000-2050).

VIETNAM: 2 shells (Fig. 5G), syntypes of A. pervariabilis var. “monozonalis”, from Ban-Lao (MNHMIM-2000-2057).

VIETNAM: 1 shell (Fig. 5H), syntype of A. pervariabilis var. "obesa”, from Muong-Bo, $22^{\circ} 24^{\prime} \mathrm{N}$, $102^{\circ} 49^{\prime}$ E (MNHM-IM-2000-2053).

VIETNAM: 1 shell (Fig. 5I), syntype of A. pervariabilis var. "protracta", from Ban-Lao, Muong-Kong, Pha-Long, Pac Kha (MNHM-IM-2000-2051).

VIETNAM: 2 shells (Fig. 5J), syntypes of A. pervariabilis var. "tricolor", from Ban-Lao (MNHMIM-2000-2054).

\section{Other material}

LAOS: 3 shells (Fig. 5K-L), Km 34, road to Ban Namly, Khua District, Phongsaly, $21^{\circ} 11^{\prime} 55.5^{\prime \prime}$ N, $102^{\circ} 6^{\prime} 40.2^{\prime \prime}$ E, $834 \mathrm{~m}$ amsl (CUMZ 7014).

\section{Description}

Shell chirally dimorphic, elongate conical, rather thick and glossy. Spire elongate conical; apex acute, with or without black spot on tip. Whorls 6 to 7 convex to smooth; suture wide and shallow; last whorl rounded to well rounded. Periostracum thin corneous; varix usually absent. Shell color varies from uniform white, yellowish to reddish brown or with narrow to wide brownish peripheral and umbilical bands. Parietal callus thin and transparent. Aperture ovate to oblique elongated; peristome expanded and not reflected; lip white, brownish or purplish. Columella straight, thick or thin and white or brownish. Umbilicus imperforated.

\section{Remarks}

This species tend to have a high diversity of shell colors, with eight infra-specific names being provisionally proposed to distinguish the distinct shell shape and color patterns. We examined all the type specimens and recognized them as subspecific entities of one species.

Laidlaw \& Solem (1961) recognized this species as a synonym of A. dautzenbergi Fulton, 1899. The latter species exhibits a thin shell, yellowish with a thin faded greenish streak near the umbilicus, a white subsutural band and an elongated ovate aperture, while $A$. pervariabilis has a thick shell, monochrome or with dark brown spiral band and ovate aperture. However, the type locality of A. dautzenbergi was "Tonkin", the historical political division during the French colonial period, and it still is an uncertain boundary. The species is known from the holotype only (Sutcharit et al. 2015: fig. 6g), no specimen was found in the present study, and, therefore, the taxonomic status of A. dautzenbergi and A. pervariabilis remains to be confirmed.

Amphidromus (Amphidromus) givenchyi Geret, 1912

Figs 1, 2C, 3C, 4I; Table 1

Amphidromus givenchyi Geret, 1912: 55-56, pl. 2, figs 21-22. Type locality: Unknown. 
Amphidromus givenchyi - Laidlaw \& Solem 1961: 526, 621. — Richardson 1985: 43. — Sutcharit \& Panha 2006: 26-28, figs 4n-q, 18-19.

\section{Material examined}

LAOS: 120D + 18D juveniles (Figs 3C, 4I, CUMZ 7015), 7D specimens, in ethanol (Fig. 2C, CUMZ 7016), Thad Lor Waterfall, Salavan District, Salavan; 61D + 8D juveniles (CUMZ 7017), 2D specimens, in ethanol (CUMZ 7018), Wat Phou (Temple on the mountain), Khong Xédon District, Salavan.

\section{Remarks}

The species description, as well as the morphology of the genitalia and the radula, have been carefully presented in Sutcharit \& Panha (2006), which allows an unambiguous recognition of this species. The unique characters are a relatively medium sized (compared to other members of this genus, as shown in Table 1), ovate-conical and dextral shell; apex with black spot; aperture oblique; peristome expanded and not reflected; parietal callus thin and transparent to slightly thickened and white; shell color uniform greenish with pale to yellowish color on earlier whorl, and greenish subsutural band; genitalia contain long and slender penis, short and curved epiphallus of equal length to flagellum; proximal to enlarged and coiled appendix epiphallus; appendix short.

The early records of this species were from the Ubon Ratchathani and Kalasin Provinces of Thailand, and the Luang Phrabang and Savannakhet Provinces of Laos (Sutcharit \& Panha 2006). Here, two more localities from Salavan Province, Laos are added. All of the records are from dry dipterocarp to deciduous forests with sandstone hills. The snails were found in small holes on branches or tree trunks during the aestivation period (Fig. 3C).

Amphidromus (Amphidromus) protania Lehmann \& Maassen, 2004

Figs 1, 4H

Amphidromus (Amphidromus) protania Lehmann \& Maassen, 2004: 17-20, figs 1-4. Type locality: South Laos, Salavan Province, near Ban Donxé Village, E bank of Se Don River.

\section{Material examined}

LAOS: Dextral, holotype (RMNH 98143, Fig. 4H); 4D shells, paratypes (RMNH 98144).

\section{Remarks}

No specimen was found in this survey. Amphidromus protania has a very similar shell shape to that the dipterocarp forest species $A$. givenchyi. The genitalia contain a long and coiled proximal part of the epiphallus, with a relatively short appendix, as in A. givenchyi (Lehmann \& Maassen 2004; Sutcharit \& Panha 2006). However, the characters distinguishing it from $A$. givenchyi are the relatively smaller shell (height $26-31 \mathrm{~mm}$ in A. protania; Table 1), the yellowish shell color as well as the brownish subsutural and spiral bands on the periphery. Moreover, Lehmann \& Maassen (2004) mentioned that the brownish banding pattern had less variation. However, a brownish spiral band on the periphery can also be observed in juvenile $A$. givenchyi (see Sutcharit \& Panha 2006: fig. 4o). Moreover, this species occurs in dipterocarp forest within the range of $A$. givenchyi; therefore, it is possibly a shell color variant of $A$. givenchyi. Additional specimens for further anatomical and molecular study are desirable to test this hypothesis. 
Amphidromus (Amphidromus) syndromoideus Inkhavilay \& Panha sp. nov. urn:1sid:zoobank.org:act:26B7BD0E-55D1-494B-B057-6D7986EB36DA

Figs 1, 2D, 3D, 4J-K, 6C-D, 7D-F; Table 1

\section{Diagnosis}

The new species differs from all other known Amphidromus (Syndromus) species in having a long epiphallus and flagellum and very long appendix, both being unique characters of the nominotypical subgenus (Solem 1983; Sutcharit \& Panha 2006). The new species differs from A. roseolabiatus in having a small and thin shell, inconspicuous greenish radial streaks and about two times longer appendix. In contrast, $A$. roseolabiatus has a larger solid shell, conspicuously greenish radial streaks in fresh specimens, sometimes with a single brownish spiral band below the periphery, purplish-pink apertural lip, and a short appendix.

\section{Etymology}

The specific epithet 'syndromoideus' is from 'syndromus', an Amphidromus subgeneric name, and the suffix '-oideus', meaning 'like or resembling'. This name refers to the resemblance in shell morphology of the new species with members of the subgenus Syndromus.

\section{Type material}

\section{Holotype}

LAOS: dextral, shell height $28.2 \mathrm{~mm}$, shell width $13.4 \mathrm{~mm}$, with 61/2 whorls (CUMZ 7019, Figs 2D, 3D, 4J, 6C-D, 7D-F).

\section{Paratypes}

LAOS: 22D + 9S shells (Fig. 4K, Table, CUMZ 7020 (1); 1S specimen, in ethanol (CUMZ 7021); 1D + 1S shells (NHMUK); 1D + 1S shells (SMF).

\section{Type locality}

LAOS: Tam Narng Ann (cave), Thakhek District, Khammouan, 17²6'39.2" N, 10456'54.8" E, 163 m amsl.

\section{Description}

Shell chirally dimorphic, thin, rather small, elongate conical and glossy. Spire conical; apex acute, brownish and without black spot on tip. Whorls 5 to 6 weakly convex; suture depressed; last whorl rounded. Periostracum thin and transparent. Last whorl with narrow white subsutural band and shell color uniform yellowish with green radial streaks on last whorl (pale to inconspicuous in older whorls and empty shells); varix absent. Parietal callus thin and transparent. Aperture wide ovate; peristome weakly expanded; lip whitish or transparent. Columella straight, thickened and white. Umbilicus narrowly opened.

\section{Radula}

Each row contains about 105 (54-(3-5)-1-(3-5)-50) teeth. Central tooth small, unicuspid, with spatulotruncated cusp. Lateral teeth bicuspid; endocone cylindrical, with wide notch; ectocone large, with truncated cusp. Marginal teeth tricuspid, starting around tooth number 3 to 5; endocone small, with sharp cusp; mesocone large, with truncated cusp; ectocone smallest. Outermost teeth with curved and pointed cusp of endocone; mesocone large, with curved cusp; ectocone of triangular shape, with pointed cusp (Fig. 7D-F).

\section{Genital organs}

Atrium (at) rather short $(n=10)$. Penis (p) short and conic-shaped. Epiphallus (e) long, slender and two times longer than penis. Flagellum (fl) short, about half length of epiphallus and terminated in folded 
coil. Appendix very long, small tube extends from folded coil of flagellum, about three times as long as epiphallus. Penial retractor muscle (pr) short, thickened and inserted distally on penis. Vas deferens (vd) narrow tube connecting epiphallus and free oviduct (Fig. 6C).

Internal penial wall, proximal to genital orifice, corrugated into series of thick penial pilasters (pp) form fringe; distal to genital orifice smooth around penial verge. Penial verge (pv) small, conical and smoothsurfaced (Fig. 6D).

Vagina cylindrical, about four times as long as penis. Gametolytic duct very long, proximal to genital orifice large, coiled; distal to genital orifice tapering to small tube and connected to ovate gametolytic sac. Oviduct and albumin gland very small (Fig. 6C).

Internally, vaginal wall shows longitudinal vaginal pilasters (vp); proximal to genital orifice with smooth, thickened and continuous ridges, and distally pilasters thinner, with smooth ridges (Fig. 6D).

\section{Distribution}

This new species is currently known from the type locality only, a dry evergreen forest with limestone outcrops in the central part of Laos at Thakhek District, Khammouan Province.

\section{Remarks}

Two living snails were found during the aestivation period in a small tree hole a height of $5 \mathrm{~m}$ (Fig. 3D).

Subgenus Syndromus Pilsbry, 1900

Amphidromus (Syndromus) Pilsbry, 1900: 184.

\section{Type species}

Helix contraria Müller, 1774 by subsequent designation in Zilch (1960: 623).

\section{Diagnosis}

Shells mostly sinistral, conical to elongate conical and rather small (height 25 to $40 \mathrm{~mm}$ ), varices absent and varying in color pattern. Genital characteristics show camaenid type with short epiphallus and flagellum, appendix absent, vaginal pouch and vaginal stimulator pilaster sometimes present. Radula teeth with spatulate shape.

The subgenus Syndromus was first nominated as "Sinistral Division" for Amphidromus with a relatively smaller sinistral coiling shell (Pilsbry 1900). Until onw, the genital characters of the type species have never been examined; only Wiegmann (1894) briefly reported on the radular and jaw structures of the type species. To clarify the genitalia and radula characters of the subgenus, spirit preserved specimens in the Zoological Museum of Amsterdam (ZMA) collection were examined and are described below.

\section{Amphidromus (Syndromus) contrarius (Müller, 1774)}

Fig. $8 \mathrm{~A}-\mathrm{B}, \mathrm{E}-\mathrm{G}$

Helix contraria Müller, 1774: 95. Type locality: Unknown.

Amphidromus contrarius - Wiegmann 1894: 208-210, pl. 15, figs 12-17. — Fulton 1896: 77- 8. Pilsbry 1900: 210-212, pl. 65, figs 22-27. — Haniel 1921: 1-88, pls 1-5. - Zilch 1960: 623, fig. 2183. — Laidlaw \& Solem 1961: 570, 612. 

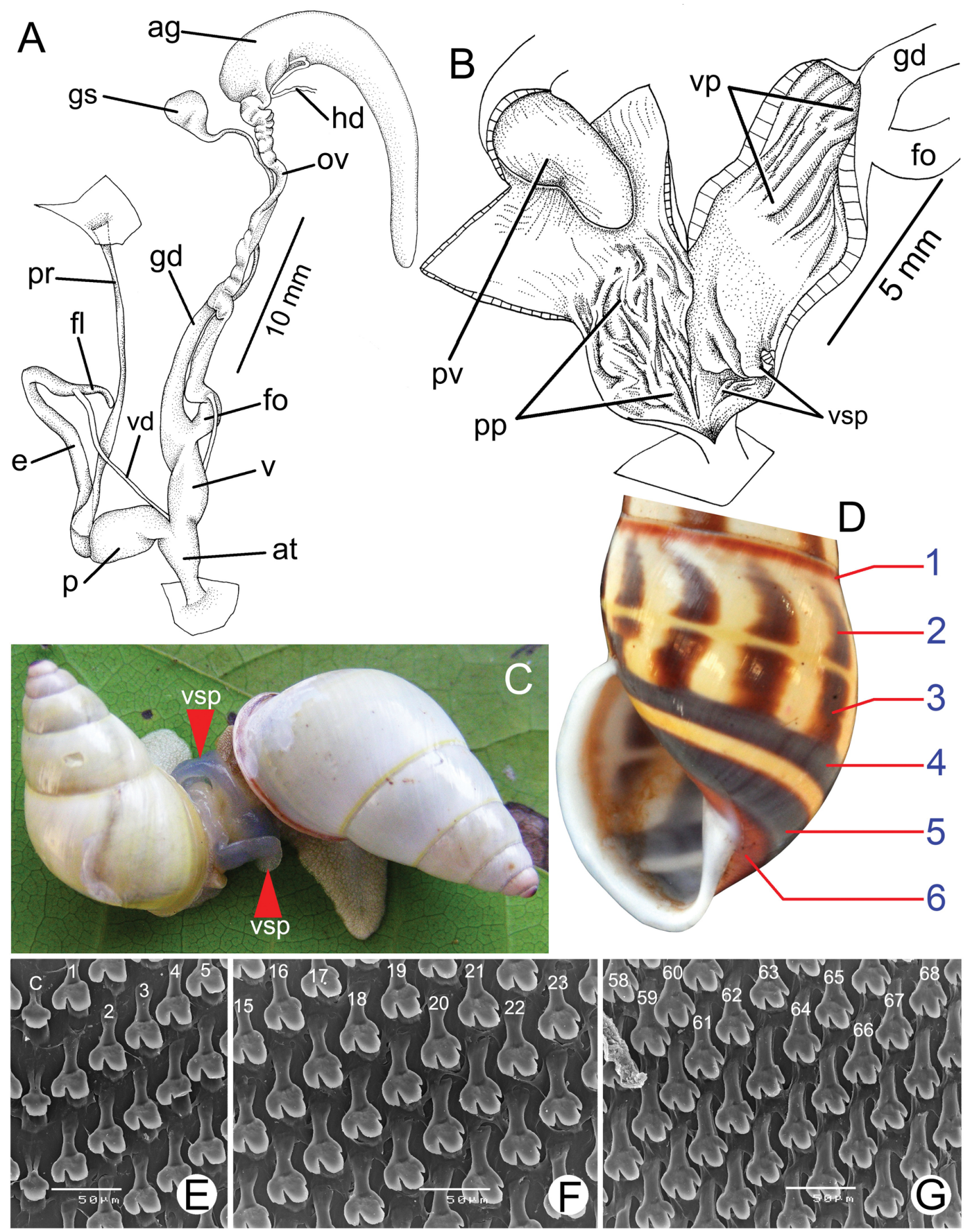

Fig. 8. Genitalia, mating pairs, shell banding formula and radula morphology. A-B. Amphidromus (Syndromus) contrarius (Müller, 1774) from Timor (ZMA). A. Genital system. B. Internal structures of penis and vagina. C. Mating pair of Amphidromus (Syndromus) sp., showing the protruded vaginal simulator pilaster (vsp, red arrows) and its possible function as a stimulating organ. D. Schematic drawing of shell banding, where the numbers 1 to 6 on the last whorl indicate the position of each band. E-G. Radula morphology of Amphidromus (Syndromus) contrarius (Müller, 1774) from Timor (ZMA). E. Central tooth, with the first to fifth lateral teeth. F. Lateral teeth with the tricuspid marginal teeth transition. G. Outermost marginal teeth. Numbers indicate the order of the lateral and marginal teeth. Central tooth indicated by ' $\mathrm{C}$ '. 


\section{Material examined}

INDONESIA: ZMA collection from Niki Niki, central Timor, collected by M.E. Walsh, Mar.-Apr. 1929 [Niki Niki, Central Amanuban District, South Timor Tengah Regency, East Nusa Tenggara Province, Indonesia].

\section{Description}

\section{Shell}

Shell morphology was completely described in Pilsbry (1900: 212-213).

\section{Radula}

Teeth arranged in V-shaped rows, each row contains about 170 (83-(11-14)-1-(12-14)-86) teeth. Central tooth unicuspid, with spatulate shape. Lateral teeth bicuspid, endocone small, ectocone large, with truncated cusps, gradually transformed to tricuspid marginal teeth from about tooth number 11 to 14 outwards. Marginal teeth tricuspid, endocone with curved shape, mesocone largest, with long and obtuse cusp, and ectocone smallest, with pointed cusp (Fig. 8E-G).

\section{Genital organs}

Atrium (at) long, conical ( $\mathrm{n}=3$ ). Penis (p) short and swollen distally. Epiphallus (e) about two times as long as penis; flagellum (fl) very short and smaller than epiphallus. Appendix absent. Penial retractor muscle (pr) thin and long. Vas deferens (vd) narrow tube extending from end of epiphallus to free oviduct (Fig. 8A).

Internal penial wall, proximal to genital orifice, corrugated with obliquely penial pilasters (pp), forming fringe around penial verge; distal to genital orifice smooth. Penial verge (pv) enlarged, elongated, elliptical, with smooth surface (Fig. 8B).

Vagina (v) short, cylindrical, about same length as penis and proximal to genital orifice weakly swollen; vaginal pouch (vpo) present. Gametolytic duct (gd) long, cylindrical, almost same diameter as vagina; distally tapering to small tube and connected to spherical gametolytic sac (gs). Free oviduct (fo) short; oviduct (ov) and albumin gland very small (Fig. 8A).

Internally, vaginal wall possesses rather smooth longitudinal pilasters (vp); distally showing weak crenulation pilasters to smooth surface. Vaginal stimulator pilaster (vsp) located close to atrium, with swollen and curled shape (Fig. 8B-C).

\section{Remarks}

Approximately 45 species are currently recognized in this subgenus. Laidlaw \& Solem (1961) divided those recognized species into six supraspecific groups based on geographic distribution. All of the Indochina forms (six species) were assembled into the A. xiengensis group (Group XIV). However, the members exhibit diverse shell color patterns. Their genital characters have not yet been described. Here, we attempt to clarify those described specific entities and color forms with distinct reproductive characters and shell banding pattern.

Most of the species of the subgenus Syndromus exhibit diverse shell banding, which can be characterized in terms of five banding systems. The definitions of those five bands and description of shell color forms follow the conventional procedures used in Euhadra (Pilsbry 1928), Cepaea (Cain \& Sheppard 1950; Cain \& Currey 1963), Partula (Murray \& Clarke 1966), Theba pisana (see Cowie 1984) and Satsuma (Wu et al. 2008). The syndromid species complex maintains a polymorphic color pattern of varied width, shape and coloration. We simplify the banding pattern systems by modifying that outlined above 
and dividing them into six sections or six banding systems (Fig. 8D), starting from the uppermost of the last whorl to the lowermost near the umbilicus. They are:

Band 1 (subsutural band) just below or in contact with the suture, usually thin and sometimes omitted in some species or populations.

Bands 2 and 3 (supra-peripheral bands) begin from below Band 1 to the posterior angle of aperture. These two bands are usually separated with a narrow gap in the middle. Band 2 is located just below Band 1, and Band 3 is placed above the posterior angle of the aperture. These two bands are usually modified as dotted, blotched or divided into several thinner bands.

Bands 4 and 5 (sub-peripheral bands) located below the posterior angle of the aperture or below the periphery of the umbilicus. These two bands are usually separated by a narrow to wide gap of ground color. Band 4 normally contacts the bottom of Band 3. Band 5 is located just around the umbilicus.

Band 6 usually covers the entire umbilical area between the umbilicus and Band 5.

Amphidromus (Syndromus) areolatus (Pfeiffer, 1861)

Figs 1, 7G-I, 9A, 10A-C, 11A-B; Table 1

Bulimus areolatus Pfeiffer, 1861a: 194. Type locality: Siam [Thailand]. Pfeiffer 1861b: 172, pl. 46, figs $11-12$.

Amphidromus areolatus - Fulton 1896: 81. — Pilsbry 1900: 198-199, pl. 63, figs 85-86. — Laidlaw \& Solem 1961: 564. — Solem 1965: 624-625, pl. 1, figs 4-7. — Sutcharit et al. 2015: 58, fig. 3j-k.

\section{Material examined}

Type material

THAILAND: Lectotype NHMUK 19601430 (Sutcharit et al. 2015: fig. 3j); paralectotype NHMUK 19601431 (1 shell).

\section{Other material}

LAOS: 20 shells (Fig. 10A-C, CUMZ 7022), 17 specimens in freezer (Figs 7G-I, 9A, 11A-B, CUMZ 7023), Thad Fek, Sammakeexay District, Attapeu; 8 shells, Thad Phasoam, Paksong District, Champasak (CUMZ 7024).

\section{Description}

Shell sinistral, elongate conical, rather small, thin and glossy. Spire conical; apex acute, with black spot on tip. Whorls 5 to 6 slightly convex; suture depressed; last whorl rounded. Periostracum transparent to thin corneous. Last whorl process, with yellow to absent Band 1; Bands 2 to 4 (sometimes Bands 2 to 5) usually merge and become brownish slanted blotches with flame shape; Band 6 yellowish or roseate. Parietal callus thin and transparent. Aperture auriform; peristome expanded to weakly expanded; lip white to transparent. Columella straight and white. Umbilicus narrowly opened.

\section{Radula}

Teeth arranged in V-shaped rows, each row contains about 126 (62-(13-9)-1-(9-13)-63) teeth. Central tooth tricuspid, with triangular shaped mesocone, ectocones very small, with pointed cusp. Lateral teeth bicuspid, endocone small, with curved cusp; ectocone large, with truncate or curved cusps, gradually transformed to tricuspid marginal teeth. Tricuspid marginal teeth start around tooth number 9 to 13 outwards; endocone curve shaped; mesocone of largest size, with long and obtuse cusp; ectocone 
smallest, with pointed cusp. Outermost teeth with small serrated endocone and extocone; mesocone large, with curved cusps (Fig. 7G-I).

\section{Genital organs}

Atrium (at) rather long $(n=10)$. Penis (p) long, cylindrical and enlarged. Epiphallus (e) short, of about same length as penis; flagellum (fl) short and terminated in pointed tip. Appendix absent. Penial retractor muscle (pr) thin and relatively long. Vas deferens (vd) narrow tube connecting epiphallus and free oviduct (Fig. 11A).
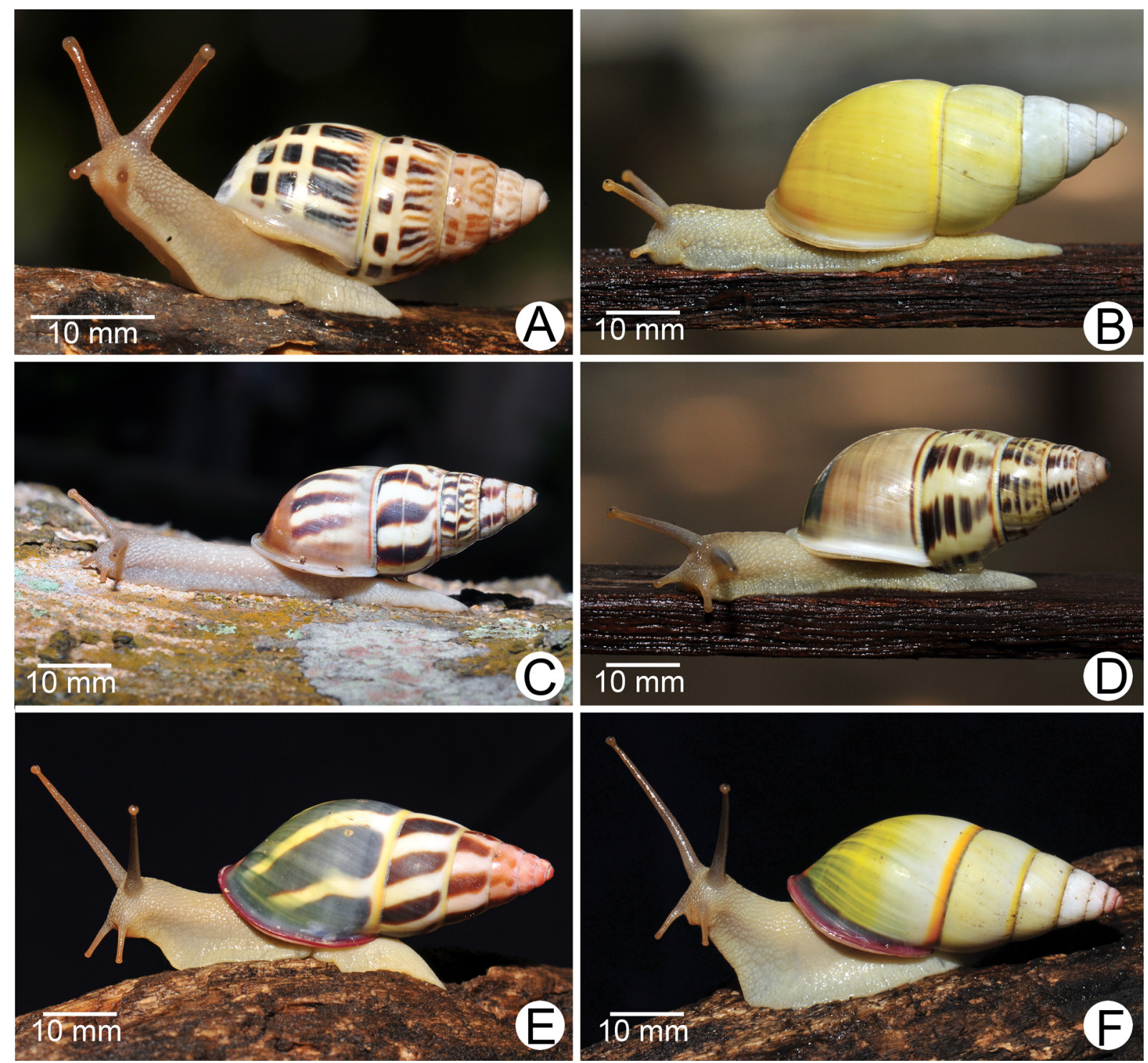

Fig. 9. Living snails of Amphidromus (Syndromus) spp. A. Amphidromus areolatus (Pfeiffer, 1861) from Thad Fek, Attapeu, Laos (CUMZ 7023). B. Amphidromus flavus (Pfeiffer, 1861) from Ban Na Deauy, Luang Phrabang, Laos (CUMZ 7027). C-D. Amphidromus xiengensis Morlet, 1891 from Thad Kacham, Luang Phrabang, Laos (CUMZ 7035), the typical form, and var. "multifasciata" Fulton, 1896, respectively. E-F. Amphidromus fuscolabris Möllendorff, 1898 from Ban Phone, Sekong, Laos (CUMZ 7041-7042). E. Typical color form. F. Monochrome yellowish color form. 
Internal penial wall nearly smooth and corrugated into thin penial pilasters, which form fringe around penial verge. Penial verge rather small, conical, with smooth surface (Fig. 11B).

Vagina cylindrical, of about same length as penis. Gametolytic duct long, proximal to genital orifice, of larger diameter than vagina and coiled; distal to genital orifice tapering to small tube of about same length as proximal part and connected to gametolytic sac. Oviduct and albumin gland very small (Fig. 11A).
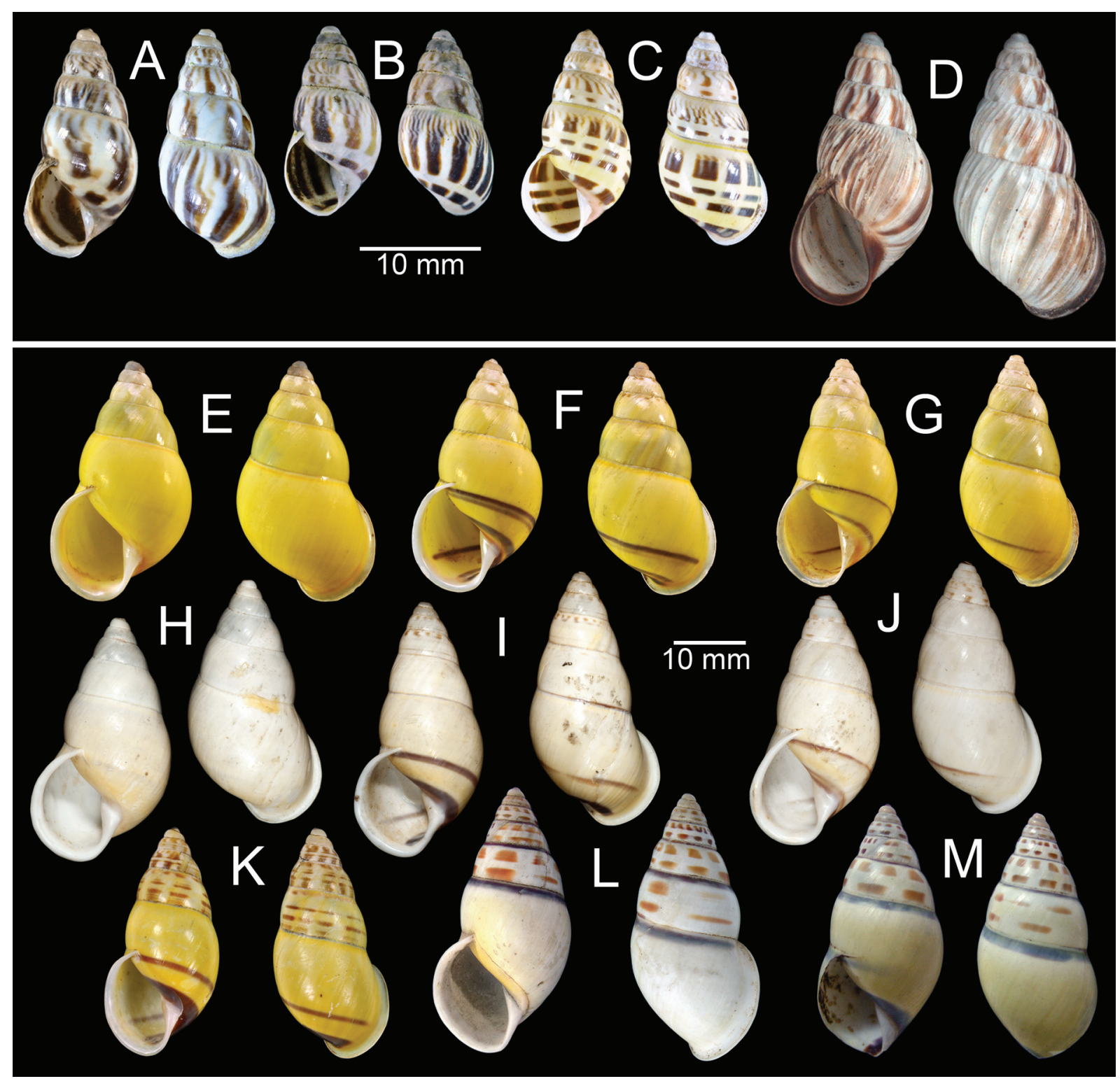

Fig. 10. Shells of Amphidromus (Syndromus) spp. A-C. Amphidromus areolatus (Pfeiffer, 1861) from Thad Fek, Attapeu, Laos (CUMZ 7022). D. Amphidromus begini (Morlet, 1886), syntype from StrungTrang, Cambodia (MNHN-IM-2000-1832). E-G. Amphidromus flavus (Pfeiffer, 1861) from Tam Pou Kham, Vientiane, Laos (CUMZ 7029). H. Amphidromus flavus var. "indistinctus" Pilsbry, 1900, holotype (ANSP 31486). I-K. Amphidromus flavus var. "tryoni" Pilsbry, 1900. I. Lectotype (ANSP 31488). J. Paralectotype (ANSP 252745). K. Specimen from Ban Na Deauy, Luang Phrabang, Laos (CUMZ 7026). L-M. Amphidromus semitessellatus (Morlet, 1884). L. Lectotype (MNHN-IM-2000-1985). M. Specimen from Cambodia (NHMUK). 


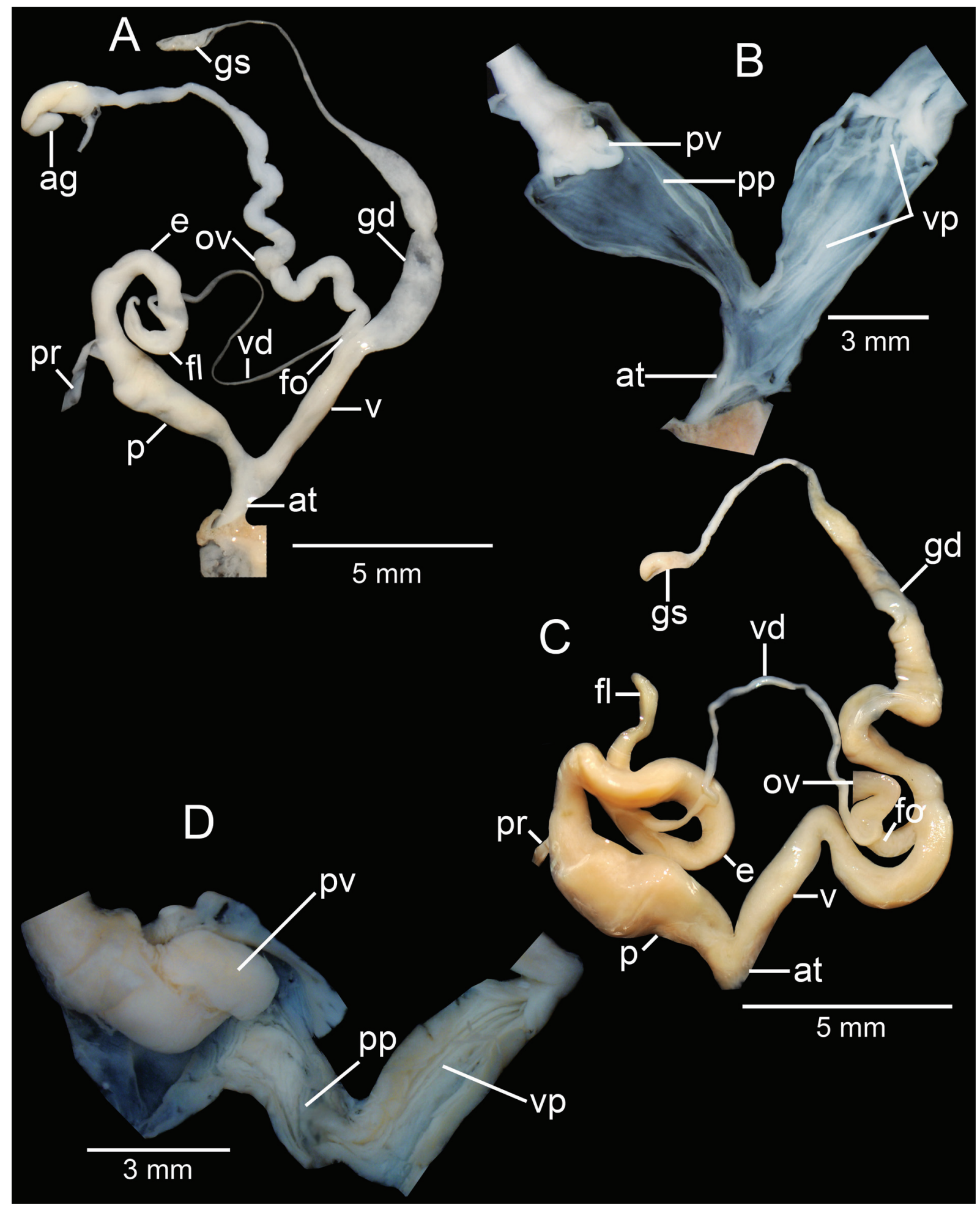

Fig. 11. Genitalia of Amphidromus (Syndromus) spp. A-B. Amphidromus areolatus (Pfeiffer, 1861) from Thad Fek, Attapeu, Laos showing the reproductive system and interior structures of the penis and vaginal chamber (CUMZ 7023). C-D. Amphidromus flavus (Pfeiffer, 1861) from Ban Na Deauy, Luang Phrabang, Laos showing the general characteristics of the genital system and the interior structures of the penis, atrium and vagina chamber (CUMZ 7027). 
Internal wall of vagina shows longitudinal vaginal pilasters (vp); proximal to genital orifice with nearly smooth surface for about half of its length, distally pilasters become corrugated ridges (Fig. 11B).

\section{Distribution}

The species is known from southern Laos, where the specimens were collected at Thad Fek, Sammakeexay District, Attapue and Thad Phasoam, Paksong District, Champasak in a dry dipterocarp forest.

\section{Remarks}

This species can be distinguished from A. zebrinus (Pfeiffer, 1861) and A. begini (Morlet, 1886) by its having a smooth shell surface and brownish spiral Bands 4 and 5 present, with white lip. In contrast, A. zebrinus (see Sutcharit et al. 2015: fig. 15k) has an elongate conical shell shape, Band 1 absent, Bands 2 to 5 merged and developing slanted radial streaks, as well as a reddish band between Bands 5 and 6 . Amphidromus begini exhibits strong radial ridges, Bands 2 to 6 merged and developing slanted brownish radial streaks, and brownish ribs (Fig. 10D, syntype MNHN-IM-2000-1832).

\section{Amphidromus (Syndromus) flavus (Pfeiffer, 1861)}

Figs 1, 9B, 10E-K, 11C-D, 12A-C; Table 1

Bulimus flavus Pfeiffer, 1861a: 194. Type locality: Siam [Thailand].

Amphidromus flavus var. proxima Fulton, 1896: 81, pl. 6, fig. 4. Type locality: Unknown. Sutcharit et al. 2015: 85, fig. 13c.

Amphidromus xiengensis var. tryoni Pilsbry, 1900: 196-197, pl. 63, fig. 78. Type locality: Laos Mountains, Cambodia.

Amphidromus sinensis var. indistinctus Pilsbry, 1900: 192, pl. 62, fig. 70. Type locality: Laos Mountains, Cambodia.

Bulimus flavus - Pfeiffer 1861b: 171, pl. 46, figs 7-8. - Morelet 1875: 265.

Amphidromus flavus - Fulton 1896: 81. — Ancey 1898: 134. — Pilsbry 1900: 197-198, pl. 63, figs 92-93. — Laidlaw \& Solem 1961: 563-564, 619.

Amphidromus flavus var. proximus - Pilsbry, 1900: 198, pl. 63, fig. 94.

Amphidromus xiengensis var. proxima - Laidlaw \& Solem 1961: 565, 652.

\section{Material examined}

Type material

THAILAND: Lectotype, NHMUK 19601436 (Sutcharit et al. 2015: fig. 7i); paralectotype, NHMUK 19601437 (1 shell).

UNKNOWN LOCALITY: Holotype of var. "proxima" Fulton, 1896, NHMUK 1896.6.13.48 (Sutcharit et al. 2015: fig. 13c).

CAMBODIA: Holotype of var. “indistinctus” Pilsbry, 1900, ANSP 31486 (Fig. 10H).

CAMBODIA: Lectotype of var. "tryoni" Pilsbry, 1900, ANSP 31488 (Fig. 10I); paralectoypes, ANSP 252745 (2 shells, Fig. 10J).

\section{Other material}

LAOS: 5 shells, park at the temple mountain, Luang Phrabang (NHMUK ex. Brandt collection No. 17320); 20 shells, Tempelberg (Temple Mount), Luang Phrabang (ZMB ex. Lehmann collection); 33 shells, Wat Phousy (temple), Luang Phrabang (CUMZ 7025); 3 shells (Fig. 10K, CUMZ 7026), 7 specimens, in ethanol (Figs 9B, 11C-D, 12A-C, CUMZ 7027), Ban Na Deauy, Luang Phrabang 
District, Luang Phrabang; 5 shells, Mouhot's Tomb, E bank of Kan River, Luang Phrabang District, Luang Phrabang (CUMZ 7028); 16 shells (Fig. 10E-G), Tam Pou Kham, Vang Vieng District, Vientiane (CUMZ 7029).

\section{Description}

Shell sinistral, small, ovate conical, small, thin and glossy. Spire conical; apex acute yellowish, with black spot on tip. Whorls 5 and 6 convex; suture depressed; last whorl rounded to well rounded. Periostracum transparent to thin corneous. Last whorl processes uniform yellowish; Bands 1 to 3 usually absent; Bands 4 and 5 absent or present with indistinct bands; Band 6 usually absent or sometimes present as scantly reddish band. Parietal callus thin and transparent. Aperture ovate to sub-ovate; peristome weakly thickened and shortly expanded; lip whitish. Columella straight and white. Umbilicus opened to narrowly opened.
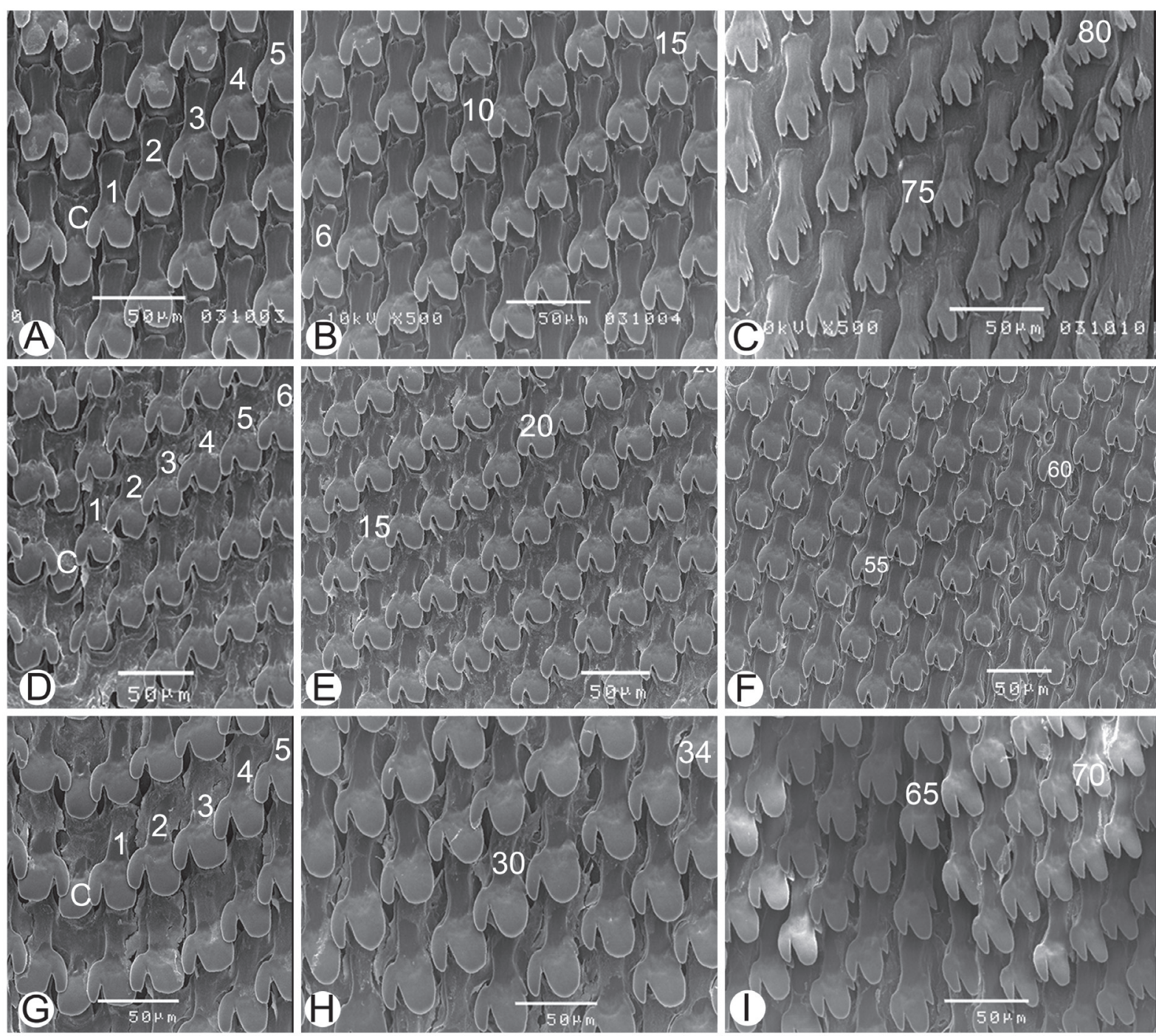

Fig. 12. SEM images of the radula. A-C. Amphidromus flavus (Pfeiffer, 1861) from Ban Na Deauy, Luang Phrabang, Laos (CUMZ 7027). D-F. Amphidromus xiengensis Morlet, 1891 from Ban Na Deauy, Luang Phrabang, Laos (CUMZ 7037). G-I. Amphidromus fuscolabris Möllendorff, 1898 from Ban Phone, Sekong, Laos (CUMZ 7041). A, D, G = central tooth with the first to fifth or sixth lateral teeth; $\mathrm{B}, \mathrm{E}, \mathrm{H}=$ lateral teeth with the tricuspid marginal teeth transition; C, F, I = outermost marginal teeth. Numbers indicate the order of the lateral and marginal teeth. Central tooth indicated by ' $\mathrm{C}$ '. 


\section{Radula}

Teeth arranged in V-shaped rows, each row contains about 166 (84-(7-10)-1-(8-12)-81) teeth. Central tooth tricuspid; mesocone of triangular shape; ectocones small, with pointed cusp. Lateral teeth tricuspid; endocone small and rounded cusps; mesocone large and truncated cusp; ectocone very small, pointed cusp and located at base of teeth. Lateral teeth gradually transformed to elongated marginal teeth. Marginal teeth tricuspid, start around tooth number 8 to 12; endocone elongate with dull cusps and separated from mesocome by wide notch; mesocone large, elongate and curved cusps; ectocone small, with pointed cusps or sometimes serrated shape (Fig. 12A-C).

\section{Genital organs}

Atrium (at) rather long $(n=5)$. Penis (p) long, cylindrical and enlarged from middle to end. Epiphallus (e) cylindrical, length longer than that of penis; flagellum (fl) short and one fourth as long as epiphallus; appendix absent. Penial retractor muscle (pr) thickened and relatively short. Vas deferens (vd) small tube, connecting epiphallus and free oviduct (Fig. 11C).

Internal penial wall corrugated into thin penial pilasters, which form fringe around penial verge. Penial verge conical, with smooth surface and orifice open near tip (Fig. 11D).

Vagina cylindrical, long, slender about two times as long as penis length. Gametolytic duct long, proximal to genital orifice almost same diameter as vagina, distally tapering; distal to genital orifice small tube of about same length as proximal part and connected to gametolytic sac. Oviduct and albumin gland small (Fig. 11C).

Internally, vaginal wall shows longitudinal vaginal pilasters (vp); pilasters very narrow and thin (Fig. 11D).

\section{Distribution}

The distribution range of the species is from Vientiane to Luang Phrabang Provinces.

\section{Remarks}

Amphidromus flavus differs from A. sinensis (Benson, 1851) in having a smaller shell, the spire more ovate and conical, with a single reddish band on the penultimate whorl. It can be distinguished from $A$. xiengensis in having a smaller shell, ovate conical, without any band on yellowish ground color or on shell sculpture. It differs from A. globonevilli Sutcharit \& Panha, 2015 by having a larger shell size, and it is smaller than A. principalis Sutcharit \& Panha, 2015. In comparison, A. globonevilli has an elongate conical shell and a faint yellow spiral band below the periphery, while $A$. principalis has a more elongate conical shell, last whorl without any band, aperture ovate. In our collection we found two types identified as A. flavus and A. flavus var. "proxima", living sympatrically at Luang Phrabang and Vang Vieng.

Three subspecific entities have been proposed; however, we recognize them as a single biological species, A. flavus.

1. Typical form: monochrome yellowish shell and Bands 1 to 6 absent (Sutcharit et al. 2015: fig. 7i-j, for the lectotype and paralectotype).

2. var. "proxima" Fulton, 1896: monochrome yellowish shell, Bands 4 and 5 are indistinct pale brownish bands (Sutcharit et al. 2015: fig. 13c, for the holotype).

3. var. "tryoni" Pilsbry, 1900: Band 1 yellowish, Bands 2 and 3 absent, Bands 4 and 5 brownish and Band 6 absent. In some specimens, brownish blotches of Bands 2 and 3 present in the earlier whorls and disappeared in the penultimate and last whorls (Fig. 10I-K).

4. var. "indistinctus" Pilsbry, 1900: identical to var. "proxima Fulton, 1896" (Fig. 10H). 
Amphidromus (Syndromus) roemeri (Pfeiffer, 1863)

Bulimus römeri Pfeiffer, 1863a [1862]: 274, pl. 36, fig. 4. Type locality: Laos Mountains, Camboja [sic].

Amphidromus roemeri - Pfeiffer 1863b (1860-1866): 217, pl. 57, figs 10-11.— Fulton 1896: 80. — Pilsbry 1900: 192-193, pl. 63, figs 95-96. - Laidlaw \& Solem 1961: 654. - Sutcharit et al. 2015: 87 , fig. $13 \mathrm{e}-\mathrm{f}$.

\section{Material examined}

CAMBODIA: Lectotype, NHMUK 19601450 (Sutcharit et al. 2015: fig. 13e); paralectotype, NHMUK 19601451 (1 shell).

\section{Remarks}

The type specimens have recently been figured in Sutcharit et al. (2015: fig. 13e-f). The unique characters of this species are the sinistral, ovate conical shell; spire with a brownish color; last whorl well rounded. Shell whitish ground color, Bands 1 to 3 and 6 absent and Bands 4 and 5 perform reddish brown bands. Aperture ovate; peristome weakly expanded; lip white.

Amphidromus roemeri was described based on specimens collected by H. Mouhot with the type locality "Laos Mountains, Camboja". This collection locality is a historical geographic name with an uncertain boundary. So far, this species is known only from the type specimens and an uncertain record from Laos by Laidlaw \& Solem (1960: 654). However, no specimens were found in the present study; therefore the records from Laos still remain to be confirmed.

Laidlaw \& Solem (1961) placed A. roemeri as a junior synonym of A. sinensis (Benson, 1851) from $\mathrm{S}$ China. We have examined the type specimens of both species and found that $A$. roemeri differs from A. sinensis by having an ovate conical, whitish shell, aperture ovate, spire short and conical, last whorl well rounded (see Sutcharit et al. 2015: fig. 13e-f). In contrast, A. sinensis (see Sutcharit et al. 2015: fig. $16 \mathrm{~g}-\mathrm{i}$ ) has a yellowish shell, elongate conical spire, aperture auriform and the last whorl rounded. Furthermore, A. globonevilli differs by having a larger, spired conical, yellowish shell and an oblique aperture.

\section{Amphidromus (Syndromus) semitessellatus (Morlet, 1884)}

Fig. 10L-M

Bulimus (Amphidromus) semitessellatus Morlet, 1884: 387, 388, pl. 11, figs 2, 2a. Type locality: "Les montagnes qui bordent le grand fleuve au delà de Stung-Treng. Les forêts et les montagnes de Kampot à Campong-Som" (Mountains along the great river behind Stung-Treng. Forests and mountains of Kampot and Sihanoukville Provinces, Cambodia).

Amphidromus semitessellatus - Morlet 1889: 128. — Fulton 1896: 87. — Pilsbry 1900: 194, pl. 60, figs 41-44. — Laidlaw \& Solem 1961: 564. — Solem 1965: 625-626, pl. 2, fig. 2. — Richardson 1985: 43. Bulimus (Amphidromus) semitessellatus - Fischer-Piette 1950: 153.

\section{Material examined}

This species was described from specimens collected by A. Pavie from the L. Morlet collection. The original description includes an illustration of a single shell, one set of shell measurements, and a species description that may be based on one unknown specimen. There is a single specimen of L. Morlet in the MNHN collections, with an original label stating "Type". Fischer-Piette (1950: 153) wrote the "holotype, $35 \mathrm{~mm}$ ", which we consider to be an inadvertent lectotype designation (ICZN 1999: Art. 
74.5). Therefore, lectotype MNHN-IM-2000-1985 (Fig. 10L) was designated by Fischer-Piette (1950: 153) to stabilise the name.

CAMBODIA: 3 shells (RBINS Dautzenberg collection); 1 juvenile (Fig. 10M) (NHMUK).

\section{Description}

Shell sinistral, elongate conical, thickened and glossy. Spire conical; apex acute, with brown or black spot on tip. Whorls 6 to 7 slightly convex; suture depressed; last whorl rounded. Periostracum thin. Last whorl monochrome whitish, with black Band 1 and Bands 2 to 6 absent; spire with concurrent brownish blotches of Bands 2 and 3. Parietal callus thickened and transparent or white. Aperture subovate; peristome rather thickened, expanded and weakly reflected; lip whitish. Columella thickened, perpendicular and white. Umbilicus narrowly opened to perforate.

\section{Remarks}

Previous records of this species were from the type locality in Stung Treng Province in the north and Kampot and Sihanoukville Provinces in the south of Cambodia, and later from Srakeo Province, Thailand. Laidlaw \& Solem (1961: 658) mentioned that the distribution range of this species was in Laos. However, no specimens were collected and, therefore, new records of this species in Laos are required to confirm its precise distribution.

Amphidromus semitessellatus can be distinguished from A. flavus and A. xiengensis by having a solid shell, with black Band 1, last whorl monochrome whitish, Bands 2 to 6 absent, and spire with concurrent brownish blotches of Bands 2 and 3. In comparison, A. flavus has a yellowish and thin shell, Bands 1 to 6 usually absent, but sometimes Bands 4 and 5 present and with scantly reddish Band 6 . Meanwhile, A. xiengensis exhibits a yellowish ground color, thinner shell, reddish Band 1, Bands 2 and 3 with concurrent brownish slanted blotches, dark brown Bands 4 and 5, and yellowish or reddish Band 6 .

Similar to the previous species, color variation occurs in this species in having concurrent brownish blotches of Bands 2 and 3 on the first half of the last whorl and blackish spiral Bands 4 and 5 present, but not continuing to the lip, and a black Band 6 .

Amphidromus (Syndromus) xiengensis Morlet, 1891

Figs 1, 9C-D, 12D-F, 13A-H, 14A-B; Table 1

Amphidromus xiengensis Morlet, 1891a: 27. Type locality: "Xieng-Mai et les forêts des bords du Ménam Pinh, Laos occidental" (banks of Ping River, Chiang Mai Province, Thailand).

Amphidromus contrarius var. multifasciata Fulton, 1896: 78, pl. 7, fig. 5. Type locality: Cambodia. Amphidromus xiengensis var. clausus Pilsbry, 1900: 195-196, pl. 63, figs 79-82. Type locality: Laos Mountain, Cambodia.

Amphidromus porcellanus var. xiengensis - Fulton 1896: 79.

Amphidromus xiengensis - Morlet 1891b: 232, 240-241, pl. 5, fig. 4. — Ancey 1898: 134. — Pilsbry 1900: 194-195, pl. 63, figs 75-76. — Fischer-Piette 1950: 159. — Laidlaw \& Solem 1961: 564565. - Solem 1965: 626-627, pl. 2, figs 7-13.

Amphidromus xiengensis var. clausus - Solem 1965: 626, pl. 2, figs 11-13.

Amphidromus xiengensis var. multifasciatus - Pilsbry 1900: 195, pl. 63, fig. 77. — Solem 1965: 626.

\section{Material examined}

The species was described based on material from Muséum (MNHN) ex. A. Pavie Collection and did not include an illustration. Morlet (1891b) subsequently re-published the description and illustrated a 


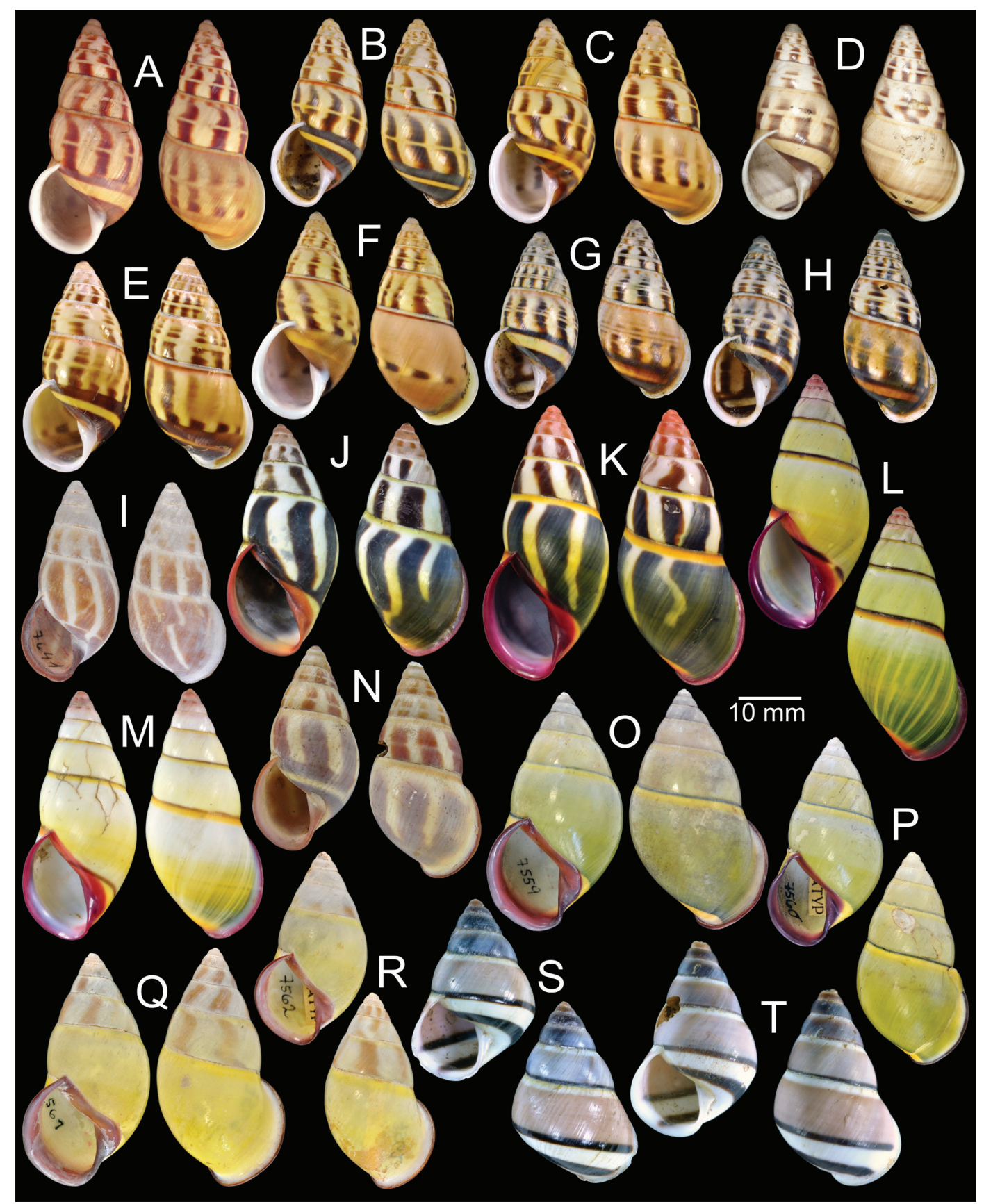

Fig. 13. Shells of Amphidromus (Syndromus) spp. A-C. Amphidromus xiengensis Morlet, 1891. A. Lectotype (MNHN-IM-2000-5249). B. Specimen from Thailand (CUMZ 7050). C. Specimen from Tam Chiang Dao, Chiangmai, Thailand (CUMZ 7034). D-F. Amphidromus xiengensis var. "clausus" Pilsbry, 1900. D. Lectotype (ANSP 31496). E. Specimen from Ban Na Deauy, Luang Phrabang, Laos (CUMZ 7036). F. Specimen from Pha Tang, Prayao, Thailand (CUMZ 7052). G-H. Amphidromus xiengensis var. "multifasciata" Fulton, 1896 from Phu Nang National Park, Phayao, Thailand (CUMZ 7038). I-M. Amphidromus fuscolabris Möllendorff, 1898. I. Holotype (SMF 7641). J-M. Specimens from Ban Phon, Sekong, Laos (CUMZ 7041-7042). N. Amphidromus eudeli Ancey, 1897, syntype from Binh Dinh, Annam (RBINS 617427). O-P. Amphidromus haematostoma Möllendorff, 1898. O. Lectotype (SMF 7559). P. Paralectotype (SMF 7560). Q-R. Amphidromus haematostoma var. "varians" Möllendorff, 1898. Q. Lectotype (SMF 7561). R. Paralectotype (SMF 7562). S-T. Amphidromus xiengkhaungensis sp. nov. S. Holotype (CUMZ 7045). T. Paratype (CUMZ 7046). 


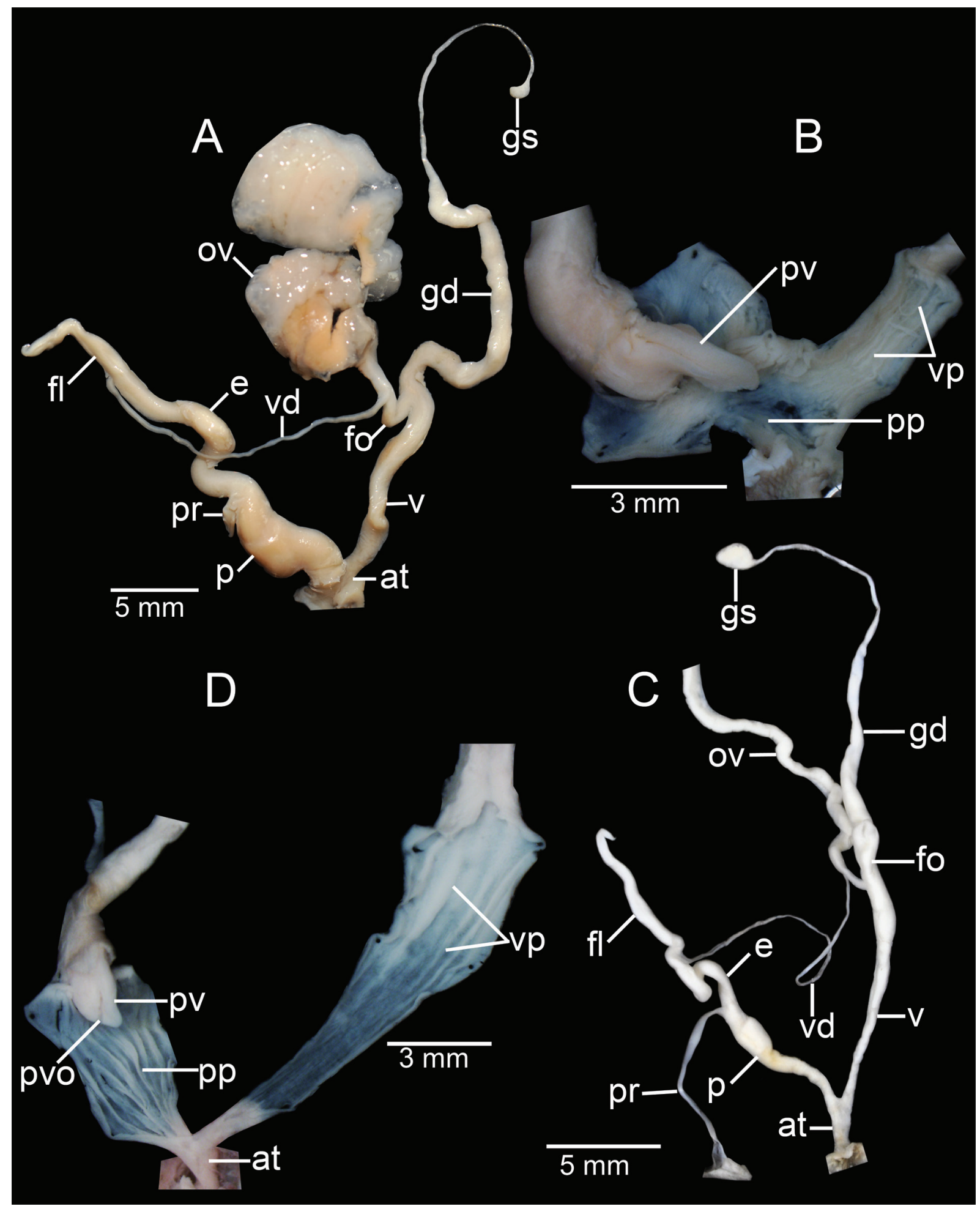

Fig. 14. Genitalia of Amphidromus (Syndromus) spp. A-B. Amphidromus xiengensis Morlet, 1891 from Luang Phrabang showing the reproductive system and interior structures of the penis and vaginal chamber (CUMZ 7035). C-D. Amphidromus fuscolabris Möllendorff, 1898 from Ban Phone, Sekong, Laos showing the general characteristics of the genital system and the interior structures of the penis, atrium and vaginal chamber (CUMZ 7041). 
single specimen. There is a single specimen of L. Morlet in the MNHN collection with an original label stating "Type". Fischer-Piette (1950: 159) wrote the "holotype, $38 \mathrm{~mm}$ ", which we consider to be an inadvertent lectotype designation (ICZN 1999: Art. 74.5). Therefore, lectotype MNHN-IM-130306224 (Fig. 8A) was designated by Fischer-Piette (1950: 153) to stabilise the name.

\section{Type material}

CAMBODIA: lectotype of var. "multifasciata" Fulton, 1896, NHMUK 19601458 (Sutcharit et al. 2015: fig. 11f); paralectotypes, NHMUK 19601459 (2 shells).

CAMBODIA: lectotype of var. “clausus” Pilsbry, 1900, ANSP 31496 (Fig. 11D); paralectotypes, ANSP 252752 (2 shells).

\section{Other material}

LAOS: 1 shell, Xieng-Moi (W Laos) (NHMUK 1893.12.8.40, ex. Dautzenberg collection); 32 shells, Ban Phon Pai, Bachieng District, Champasak (CUMZ 7030); 9 shells, Thad Phasoam, Boloven Plateau, Paksong District, Champasak (CUMZ 7031); 6 shells, Ban Oudom, Pakbeng District, Oudomxay (CUMZ 7032); 7 shells, Mouhot's Tomb, E bank of Kan River, Luang Phrabang District, Luang Phrabang (CUMZ 7033); 2 specimens, in ethanol (Figs 9C-D, 14A-B), Thad Kacham Waterfall, Luang Phrabang District, Luang Phrabang (CUMZ 7035); 4 shells (Fig. 13E, CUMZ 7036), 2 specimens, in ethanol (Fig. 12D-F, CUMZ 7037), Ban Na Deauy, Luang Phrabang District, Luang Phrabang; 1 specimen, in ethanol, Thad Khaungsy Waterfall, Luang Phrabang District, Luang Phrabang (CUMZ 7039).

CAMBODIA: 1 shell, Dautzenberg collection (RBINS); 3 shells, Lao Moutains (NHMUK 19601539, ex. Cuming Collection).

THAILAND: 1 shell (Fig. 13B, CUMZ 7050); 1 shell (Fig. 13C), Tam Chiang Dao, Chiang Dao District, Chiang Mai (CUMZ 7034); 1 shell (Fig. 13F), Pha Tang, Pong District, Prayao (CUMZ 7052); 3 shells (Fig. 13G-H), Doi Phou Nang National Park, Chiangmouan District, Phayao (CUMZ 7038).

\section{Description}

Shell sinistral, conical to elongate conical, rather thick and glossy. Spire conical; apex acute with brown or black spot on tip. Whorls 6 to 7 slightly convex; suture depressed; last whorl rounded. Periostracum thin and corneous. Last whorl with reddish to brown Band 1; Bands 2 and 3 as concurrent slanted brownish blotches continuous to expanded lip; Bands 4 and 5 with brownish spiral bands; Band 6 absent or yellowish to reddish. Parietal callus transparent or weakly thickened and white. Aperture subovate; peristome rather thick and expanded; lip whitish. Columella thickened, perpendicular and white. Umbilicus narrowly opened to perforated.

\section{Radula}

Each row contains about 157 (79-(21-17)-1-(17-21)-77) teeth. Central tooth monocuspid, with spatulate shape. Lateral teeth bicuspid; endocone with elongate shape, curved cusp and separated from truncated or curved cusps of ectocone by wide notch, teeth gradually transformed to tricuspid marginal teeth. Marginal teeth tricuspid starting around teeth number 17 to 21 outwards; endocone curved and pointed cusps; mesocone large, with truncate or obtuse cusps; ectocone small, of triangular shape, with pointed cusp. Outermost teeth with pointed cusps on endocone; mesocone large, with curved cusps; extocone sometimes with serrated shape (Fig. 12D-F).

\section{Genital organs}

Atrium (at) somewhat short ( $\mathrm{n}=5$ ). Penis (p) long, cylindrical and enlarged at middle. Epiphallus (e) cylindrical, two times as long as penis; flagellum (fl) short, one third as long as epiphallus; appendix 
absent. Penial retractor muscle (pr) thickened and relatively short. Vas deferens (vd) small tube, connecting epiphallus and free oviduct (Fig. 14A).

Internal penial wall corrugated into weak penial pilasters, which form fringe around penial verge. Penial verge conical, rough surface and orifice open near tip (Fig. 14B).

Vagina cylindrical, long, slender, about 1.5 times as long as penis. Gametolytic duct long, proximal to genital orifice of same diameter as vagina and distally tapering; distal to genital orifice very small tube of about same length as proximal part and connected to gametolytic sac. Oviduct and albumin gland very large (Fig. 14A).

Internal wall of vagina shows longitudinal vaginal pilasters (vp); pilasters vary narrow and thin throughout vaginal length (Fig. 14B).

\section{Distribution}

The species is widely distributed and can be found in several habitats such as forests, fruit orchards and limestone areas between latitudes $14^{\circ}$ and $16^{\circ} \mathrm{N}$.

\section{Remarks}

Amphidromus xiengensis differs from A. areolatus and A. zebrinus in having a larger shell, reddish Band 1, concurrent slanted and brownish blotched Bands 2 and 3, and brownish spiral Bands 4 and 5. In contrast, the other two species have a smaller shell, Band 1 absent and Bands 2 and 3 merged and becoming brownish slanted blotches in A. zebrinus or brownish slanted blotches with a flame shape in A. areolatus. It differs from A. eudeli Ancey, 1897 (Fig. 13N, syntype RBINS 617427) and A. fuscolabris Möllendorff, 1898 (Fig. 13I, holotype SMF 7641) in having a white peristome, reddish Band 1, and Bands 2 and 3 usually separated. In comparison, A. fuscolabris shows a purplish-pink peristome, yellowish Band 1, Bands 2 to 5 merged and roseated Band 6, while A. eudeli exhibits a brownish lip, yellow color Band 1 and Bands 2 and 3 usually merged.

Two subspecific entities have been proposed; we, however, recognize them as a single biological species, A. xiengensis.

1. Typical form: Band 1 reddish to brownish; Bands 2 and 3 concurrent slanted brownish blotches continuous to expanded lip; Bands 4 and 5 brownish spiral band; Band 6 absent (Fig. 13A-C).

2. var. "multifasciata" Fulton, 1896: similar to the typical form, but Band 1 yellowish; Bands 2 and 3 usually divided into several smaller bands; Band 6 reddish (Fig. 13G-H; Sutcharit et al. 2015: fig. $11 \mathrm{f}-\mathrm{g})$.

3. var. "clausus" Pilsbry, 1900: similar to the typical form and var. "multifasciata", but Bands 2 and 3 have disappeared and turned to a pinkish stain on the second half of the last whorl (Fig. 13D-F).

Amphidromus (Syndromus) fuscolabris Möllendorff, 1898

Figs 1, 9E-F, 12G-I, 13J-M, 14C-D; Table 1

Amphidromus zebrinus fuscolabris Möllendorff, 1898: 75. Type locality: Boloven (Boloven Plateau, Paksong District, Champasak, Laos).

Amphidromus zebrinus fuscolabris - Pilsbry 1900: 199-200. — Zilch 1953: 134, pl. 23, fig. 22. Laidlaw \& Solem 1961: 564, 621. — Richardson 1985: 49. 


\section{Material examined}

\section{Type material}

LAOS: holotype SMF 7641 (Fig. 13I).

\section{Other material}

LAOS: 34 shells, typical form (Fig. 13J-K, CUMZ 7040); 2 specimens, in ethanol (Figs 9E, 12G-I, 14C-D, CUMZ 7041); 73 + 10 juveniles, yellowish form (Fig. 13L-M, CUMZ 7042); 2 specimens, in ethanol (Fig. 9F, CUMZ 7043), Ban Phone, La-Marm District, Sekong; 2 shells, Ban Xai Na Pho, Phatumphone, Champasak (CUMZ 7044).

\section{Description}

Shell sinistral, elongate conical, rather solid and glossy. Spire elongate conical; apex acute, with pinkish tint to brownish without black spot on tip. Whorls 6 to 7 nearly smooth; suture wide and shallow; last whorl rounded. Periostracum transparent to thin corneous, with greenish streaks on lower half of last whorl. Last whorl shows yellow to orange Band 1; Bands 2 to 5 merged and become six or seven black or brown slanted blotches; Band 6 yellow; varix absent. Parietal callus thickened, bright purplishpink. Aperture elongated auriform; peristome thickened, expanded and not reflected; lip purplish-pink. Columella rather thick, straight, dilated and purplish-pink. Umbilicus imperforated.

\section{Radula}

Each row contains about 161 (80-(35-31)-1-(31-35)-80) teeth. Central tooth unicuspid, with curved cusp. Lateral and marginal teeth similar to that described in A. areolatus. Marginal teeth start from lateral tooth 17 to 21 outwards (Fig. 12G-I).

\section{Genital organs}

Atrium (at) rather long $(\mathrm{n}=10)$. Penis (p) long, cylindrical and slightly swollen at distal end. Epiphallus (e) short, half of penis length; flagellum (fl) of about same length as epiphallus and terminated with pointed tip. Appendix absent. Penial retractor muscle (pr) thin and long. Vas deferens (vd) very narrow tube connecting epiphallus and free oviduct (Fig. 14C).

Internal penial wall corrugated into strong penial pilasters, which form fringe around penial verge. Penial verge conical, with smooth surface and orifice open near tip (Fig. 14D).

Vagina cylindrical, long, slender, about two times as long as penis. Gametolytic duct long, proximal to genital orifice of a relatively larger diameter than vagina and distally tapering; distal to genital orifice small tube of about same length as proximal part and connected to gametolytic sac. Oviduct and albumin gland very small (Fig. 14C).

Internally, vaginal wall shows longitudinal vaginal pilasters (vp); proximal to genital orifice with thin wall and smooth surface, distally pilasters show continuous ridges (Fig. 14D).

\section{Distribution}

The original description of this species was given by Möllendorff (1898) and the type locality was Boloven, Laos. Unfortunately, we couldn't obtain any specimen from the type locality in our recent survey. The specimens were collected from a mountain at Ban Phone (Phone village), Sekong Province, and Ban Xai Na Pho (Xai Na Pho village) Phatumphone, Champasak, Laos, which are both located at a lower altitude than the Boloven Plateau. It seems that this species is only found in low altitude habitats. 


\section{Remarks}

Amphidromus fuscolabris differs from A. zebrinus and A. eudeli in having a large and elongate shell, apex tinted pink, purplish-pink parietal callus, Band 1 yellowish and Bands 2 to 5 merged and becoming 6 to 7 slanted blotches (on last whorl). In comparison, A. zebrinus (see Sutcharit et al. 2015: fig. 15k) has a smaller shell, Band 1 absent, Bands 2 and 5 merged and becoming fifteen narrow slanted stripes on last whorl, and reddish band in between Bands 5 and 6. On the other hand, A. eudeli (Fig. 13N, holotype RBINS 617427) has a smaller shell, thin parietal callus, Bands 2 and 3 merged and Bands 4 and 5 well developed.

Two color forms were observed from Sekong, Laos. These are the typical form (Fig. 13I-K) and the yellowish form that is monochrome yellowish, with Bands 2 to 5 absent and stained with pale yellowish color, and Band 6 sometimes present as a brownish color (Fig. 13L-M). However, these two color forms show a pinkish to purplish-pink parietal callus and columella, and have identical genital structures and sculptures inside the penis and vagina. In addition, they occur sympatrically and so we recognize them as conspecific.

Amphidromus (Syndromus) haematostoma Möllendorff, 1898

Figs 1, 13O-R

Amphidromus haematostoma Möllendorff, 1898: 74-75. Type locality: Boloven (Boloven Plateau, Champasak, Laos).

Amphidromus haematostoma var. viridis Möllendorff, 1898: 75. Type locality: Boloven (Boloven Plateau, Champasak, Laos).

Amphidromus haematostoma var. varians Möllendorff, 1898: 75. Type locality: Boloven (Boloven Plateau, Champasak, Laos).

Amphidromus haematostoma - Pilsbry 1900: 182-183. — Zilch 1953: 132. — Laidlaw \& Solem 1961: 527, 625. - Richardson 1985: 19.

Amphidromus haematostoma var. viridis - Pilsbry 1900: 183. — Zilch 1953: 132, pl. 22, fig. 4. Laidlaw \& Solem 1961: 527, 670. — Richardson 1985: 19.

Amphidromus haematostoma var. varians - Pilsbry 1900: 183. — Zilch 1953: 132, pl. 22, fig. 5. Laidlaw \& Solem 1961: 527, 668. — Richardson 1985: 19.

Amphidromus (Syndromus) haematostomus - Lehmann \& Maassen 2004: 20.

\section{Material examined}

\section{Type material}

The species description included two varieties, "var. A. viridis" and "var. B. varians", but only one set of shell measurements was given in the original description, of the nominotypical variety. The specimen SMF 7559, labelled as "var. A. viridis", exactly matches the dimensions given in the original description. Therefore, we believe this implied that the specimens of "var. A. viridis" pertain to the type series of A. haematostomus s.s. The specimen SMF 7559 (Fig. 13O) was designated as the lectotype in Zilch (1953: 132, pl. 22, fig. 4), which is considered to be a valid lectotype designation of the species, and the other specimen from the same lot becomes the paralectotype SMF 5760 (1 shell; Fig. 13P).

The other specimens labeled as "var. B. varians" are distinct variants and are, therefore, excluded from the type series of this nominal species (ICZN 1999: Art. 72.4.1). The specimen SMF 7561 (Fig. 13Q) was designated as the lectotype in Zilch (1953: 132, pl. 22, fig. 5), which is considered to be a valid lectotype designation of "var. B. varians". Another specimen from the same lot became the paralectotype, SMF 5762 (1 shell; Fig. 13R). 


\section{Other material}

LAOS: $6+2$ juveniles, Boloven Plateau, Pakxong District, Champasak (RMNH 101050); two lots in W.J.M. Maassen Collection(8S) and (12+2 juveniles); 1 shell, Boloven, Annam (NHMUK 1899.4.22.74); 15 shells (ZMB, ex. Lehmann Collection), $5+1$ juvenile (ZMB, ex. Lehmann Collection), in coffee plantation, near Pakxong, Boloven Plateau, Champasak.

\section{Remarks}

This species is currently known from the type locality only. The shell characters are clearly distinct from all other recognized species. The shell is sinistral and ovate conical. Then apex is acute, with a black spot on the tip. The last whorl is rounded; the color of the shell is a monochrome greenish (faded in old specimen), and there are a yellowish subsutural band and an umbilical area. Then aperture is ovate; the peristome expanded and weakly reflected; the lip is reddish-purple. The parietal callus is reddish-purple and thickened; the columella is also reddish-purple and dilated; the umbilicus imperforated.

Laidlaw \& Solem (1961) suggested that this species was probably a junior synonym of A. roseolabiatus. However, after comparing the type specimens of both species and recently collected specimens of A. roseolabiatus, A. haematostoma clearly differs from it in having an ovate conical shape, uniform greenish to yellowish shell, yellowish subsutural and umbilical area, thickened parietal callus, lip widely expanded, and reddish-purple lip and parietal callus. Moreover, A. roseolabiatus exhibits an elongate conical shell, greenish radial streaks, white subsutural band, transparent parietal callus, and lip pinkish or white and expanded.

Lehmann \& Maassen (2004: 20) recorded the genital characters (without illustration) of the topotypic population and mentioned that it had a "very short flagellum and a short conical verge". These are the distinguishing characters of this subgenus. However, further investigation of the genitalia is necessary to confirm the subgeneric status.

\section{Amphidromus (Syndromus) xiengkhaungensis Inkhavilay \& Panha sp. nov. urn:1sid:zoobank.org:act:7BA4B989-3003-4F09-94E5-F21B392BEA28}

Figs 1, 13S-T; Table 1

\section{Diagnosis}

The new species is superficially similar to A. roemeri, but the distinguishing characters are a relatively large and thick shell, dark to brownish spire, Bands 2 and 3 merged and become tinted pink stained, with a pale tinted pink lip. In contrast, $A$. roemeri shows a relatively small and thin shell, whitish ground color, Bands 2 and 3 absent, and has a white lip. Amphidromus xiengkhaungensis sp. nov. differs from A. sinensis and A. flavus by having an ovated conic shell, Bands 2 and 3 stained with tinted pink, ovate aperture and slightly angular last whorl. In comparison, A. sinensis and A. flavus have an elongate conical, relatively small and thin shell, with a yellowish color and rounded last whorl. In addition, A. globonevilli differs from this new species by having a small and thin shell, with a yellowish color, last whorl rounded and Bands 2 and 3 absent.

\section{Etymology}

The specific epithet 'xiengkhaungensis' refers to the type locality of the new species.

\section{Type material}

\section{Holotype}

LAOS: shell height $25.6 \mathrm{~mm}$, shell width $15.6 \mathrm{~mm}$, with 6 whorls (CUMZ 7045, Fig. 13S).

\section{Paratypes}

LAOS: 10S shells (CUMZ 7046, Fig. 13T); 2S shells (NHMUK). 


\section{Type locality}

LAOS: limestone outcrop at Ban Nong Tang, Phou Kood District, Xieng Khaung, 19³0'59.2" N, $102^{\circ} 53^{\prime} 37.6^{\prime \prime} \mathrm{E}, 1140 \mathrm{~m}$ amsl.

\section{Description}

Shell sinistral, ovate conical, rather thick and glossy. Apex acute, color tinted pink; spire conical with dark color; suture wide and depressed. Whorls 5 and 6 nearly smooth; last whorl slightly angular. Periostracum thin, corneous and transparent. Earlier whorls with darker color; varix absent. Shell banding without Band 1; Bands 2 and 3 merged and becoming tinted pink stained; Bands 4 and 5 dark brown; Band 6 absent. Parietal callus thin and transparent to slightly thick and white. Aperture ovate; peristome expanded and weakly thickened; lip pale tinted pink to white. Columella straight, thickend and white. Umbilicus narrowly opened.

\section{Remarks}

Amphidromus xiengkhaungensis sp. nov. is currently known from the type locality only, a dry green forest and isolated limestone forest surrounded by a reservoir and agricultural areas. The empty shells were found on the floor among the leaf litter. Unfortunately, no living specimens have been collected.

\section{Discussion}

The first species of Amphidromus from Laos, A. roemeri, was described by Pfeiffer (1863a). Subsequently, A. xiengensis, A. laosianus and A. haematostoma were reported by Morlet (1891), Bavay (1898) and Möllendorff (1898), and the latest described species was A. protania by Lehmann \& Maassen (2004), collected from Ban Donxé, Salavan Province. However, there are many species for which basic information is still unclear, such as the type locality for, e.g., A. roemeri, where the author stated only "Laos Mountains" as the locality. Almost all records were from southern areas or lowlands, except for A. xiengensis, which was recorded in the north (Fig. 1).

In this paper we describe two new species, both known from their type localities only. Amphidromus syndromoideus sp. nov. has a small shell size, dextral and sinistral, green color with long epiphallus and flagellum, and very long appendix. Amphidromus xienkhaungensis sp. nov. is described based on shells only. The shell is superficially similar to that of A. roemeri, but it is larger and thicker, with a dark to brown spire. Moreover, the two recorded species Amphidromus xiengensis and A. flavus were described here using shells and genital anatomy.

In the southern part of Laos we collected the four species A. givenchyi, A. fuscolabris, A. areolatus and $A$. xiengensis. The most dominant species were $A$. givenchyi, A. fuscolabris and $A$. areolatus, which could be found between the altitudes of 140 and $190 \mathrm{~m}$ amsl. Only two species were collected in the central region of Laos, A. roseolabiatus and A. syndromoideus sp. nov., with the most dominant species being A. roseolabiatus. In the northern part of Laos we collected five species of Amphidromus; surprisingly A. roseolabiatus and A. xiengensis were found in both southern and northern Laos, but A. flavus, $A$. pervariabilis and A. xiengkhuangensis sp. nov. were only found in northern Laos, from Vang Viang to Phongsaly.

Amphidromus roseolabiatus and A. xiengensis were the most dominant and widely distributed species throughout Laos. They can be found in several habitats, even in limestone areas from the south to the north. However, A. givenchyi, A. syndromoideus sp. nov. and A. xiengkhaungensis sp. nov. were specific to their unique habitats, whereas $A$. givenchyi was restricted to the Salavan Province (southern Laos). Amphidromus syndromoideus sp. nov. is found at the type locality, Khammouan Province (central Laos), 
only and A. xiengkhaungensis sp. nov. is rare and only found in an isolated limestone area at Nong Tang Village, Xieng Khaung Province, which is between the northern and central border at $800 \mathrm{~m}$ amsl.

The occurrence of $A$. roseolabiatus and A. xiengensis in the southern, central and northern parts of Laos may suggest (i) they originally had a widespread origin, (ii) one or both have been translocated by humans or (iii) they have been subjected to long range dispersal. These hypotheses await to be resolved.

The results show that the diversity of the species of Amphidromus in Laos is low compared to that in Thailand (Panha 1996; Sutcharit et al. 2015) and Vietnam (Schileyko 2011), where 19 and 23 species are known, respectively. However, this may simply reflect a collecting bias, having been spent less survey time and a smaller number of sites in Laos having been sampled compared to the other two countries, rather than demonstrating the actual species diversity. Thus, more extensive (intensity and coverage) sampling is required.

\section{Acknowledgements}

The authors are grateful to members of the Animal Systematics Research Unit (ASRU) for kind help during field collecting. Special thanks go to the Faculty of Natural Science, National University of Laos for the preparation of permission documents during surveys and data collection in Laos. The authors express their gratitude for the comments from anonymous referees that improved the manuscript. We are also indebted to J. Ablett and F. Naggs (NHM, London), T. Backeljau (RBINS, Brussels), P. Collomon (ANSP, Philadelphia), V. Héros and M. Caballer (project E-RECOLNAT: ANR-11-INBS-0004, MNHN, Paris), R. Janssen (SMF, Frankfurt), W.J.M. Maassen (RMNH, Leiden), R.G. Moolenbeek (ZMA, Amsterdam) and T. von Rintelen (ZMB, Berlin) for their support with the type material database and photographs. This project was mainly funded by the TRF Senior Research Scholar RTA 5880002 (20152018), the Ratchadaphiseksomphot Endowment Fund of Chulalongkorn University WCU-58-016FW, and additional scholarship support from CU-ASEAN and the $90^{\text {th }}$ Anniversary of Chulalongkorn University Fund.

\section{References}

Albers J.C. 1850. Die Heliceen, nach natürlicher Verwandtschaft systematisch geordnet. Verlag von Th. Chr. Fr. Enslin, Berlin. Available from http://biodiversitylibrary.org/item/43756 [accessed 3 Jul. 2013].

Albers J.C. 1860. Die Heliceen nach natürlicher Verwandtschaft systematisch geordnet, second edition [manuscript edited by E. von Martens]. Verlag von Welhelm Engelmann, Leipzig. Available from http:// biodiversitylibrary.org/item/42934 [accessed 2Aug. 2016].

Ancey C.F. 1898. Observations sur les mollusques terrestres et fluviatiles recueillis dans l'Indo-chine et particulièrement au Laos par M.H. Counillon. Bulletin du Muséum d'Histoire naturelle de Marseille 1: 129-137.

Bavay A. 1898. Coquilles nouvelles provenant des récoltes de M. L. Levay dans le Haut-Mekong pendant la campagne du Massie (1893-95). Journal de Conchyliologie 46: 15-20. Available from http:// biodiversitylibrary.org/page/15920414 [accessed 17 Jul. 2013].

Bavay A. \& Dautzenberg P. 1909a. Description de coquilles nouvelles de l'Indo-Chine. Journal de Conchyliologie 57: 279-281. Available from http://biodiversitylibrary.org/page/27393458 [accessed 9 Oct. 2013].

Bavay A. \& Dautzenberg P. 1909b [1908]. Molluscorum terrestrium Tonkinorum diagnoses. Journal de Conchyliologie 56: 229-251. Available from http://www.biodiversitylibrary.org/page/16298225 [accessed 18 May 2017]. 
Cain A.J. \& Currey J.D. 1963. Area effects in Cepaea. Philosophical Transactions of the Royal Society of London B 246: 1-81. https://doi.org/10.1098/rstb.1963.0001

Cain A.J. \& Sheppard P.M. 1950. Selection in the polymorphic land snail Cepaea nemoralis. Heredity 4: 275-294. https://doi.org/10.1038/hdy.1950.22

Cowie R.H. 1984. Ecogenetics of Theba pisana (Pulmonata: Helicidae) at the northern edge of its range. Malacologia 25: 361-380. Available from http://biodiversitylibrary.org/page/13145484 [accessed 8 Jun. 2016].

Duncan F.M. 1937. On the dates of publication of the Society's 'Proceedings'1859-1926, with an appendix containing the dates of publication 1830-1858, compiled by F.H. Waterhouse; also of the 'Transactions' 1833-1869 by Henry Peavot, originally published in P.Z.S. 1893, 1913. Proceedings of the Zoological Society of London, Series A 107: 71-84.

Fischer-Piette E. 1950. Liste des types décrits dans le Journal de Conchyliologie et conservés dans la collection de ce journal. Journal de Conchyliologie 90: 149-180.

Fulton H.C. 1896. A list of the species of Amphidromus, Albers, with critical notes and descriptions of some hitherto undescribed species and varieties. Annals and Magazine of Natural History, Series 6 17: 66-94. Available from http://biodiversitylibrary.org/page/16006918 [accessed 19 Sept. 2013].

Geret P. 1912. Description d'un nouvel Amphidromus. Journal de Conchyliologie 60: 55-56. Available from http://biodiversitylibrary.org/page/16358498 [accessed 15 Jul. 2013].

Haniel C.B. 1921. Variationstudie an timoresischen Amphidromusarten. Zeitschrift für induktive Abstammungs- und Vererbungslehre 25: 1-88. Available from http://biodiversitylibrary.org/ page/29443900 [accessed 4 Apr. 2017].

International Code of Zoological Nomenclature [ICZN]. 1999. International Code of Zoological Nomenclature. Fourth Edition. The International Trust for Zoological Nomenclature, London.

Johnson R.I. 1969. Pfeiffer's Novitates Conchologicae, Series I, Land Mollusca, 1854-1879, and Dunker's Novitates Conchologicae, Series II, Marine Mollusca, 1862-1882. A complete collation. Journal of the Society for the Bibliography of Natural History 5: 136-239.

Laidlaw F.F. \& Solem A. 1961. The land snail genus Amphidromus: A synoptic catalogue. Fieldiana: Zoology 41: 507-677. Available from http://biodiversitylibrary.org/item/20789 [accessed 18 Jul. 2013].

Lehmann H. \& Maassen W.J.M. 2004. A new species of Amphidromus from Laos (Gastropoda, Pulmonata, Camaenidae). Basteria 68: 17-20. Available from http://natuurtijdschriften.nl/download?t ype $=$ document $\&$ docid $=597271$ [accessed 8 Jun. 2016].

Martens E. 1860. On the Mollusca of Siam. Proceedings of the Zoological Society of London 28: 6-18. Available from http://biodiversitylibrary.org/page/12866504 [accessed 3 Jul. 2013].

Möllendorff O.F. von. 1898. Die Binnenmollusken Annams. Nachrichtsblatt der deutschen Malakozoologischen Gesellschaft 30: 65-85. Available from http://www.biodiversitylibrary.org/ item/89671\#page/261/mode/1up [accessed 21 Apr. 2017].

Morelet A. 1875. Séries conchyliologiques comprenant l'Énumération de Mollusques terrestres et fuviatiles recueillies pendant le Cours de différents Voyages ainsi que la Description de plusieurs Espèces nouvelles. Fourth issue: 227-377. Klincksieck, Paris. https://doi.org/10.5962/bhl.title.11458

Morlet L. 1884. Description d'espèces nouvelles de coquilles recueillies par M. Pavie au Cambodge. Journal de Conchyliologie 32: 386-403. Available from http://biodiversitylibrary.org/page/16072179 [accessed 9 Sept. 2013].

Morlet L. 1889. Catalogue des coquilles recueillies, par M. Pavie dans le Cambodge et de le Royaume de Siam et description d'espèces nouvelles. Journal de Conchyliologie 37: 121-199. Available from http://biodiversitylibrary.org/page/16015483 [accessed 10 Sept. 2013]. 
Morlet L. 1891a. Diagnoses molluscorum novorum, in Indochinâ collectorum. Journal de Conchyliologie 39: 25-28. Available from http://biodiversitylibrary.org/page/15927626 [accessed 9 Sept. 2013].

Morlet L. 1891b. Contribution à la faune malacologique de l'Indo-Chine. Journal de Conchyliologie 39: 230-254. Available from http://biodiversitylibrary.org/page/15927831 [accessed 9 Sept. 2013].

Müller O.F. 1774. Vermium Terrestrium et Fluviatilium, Seu Animalium Infusoriorum, Helminthicorum, et Testaceorum, non Marinorum, Succincta Historia, 2. Heineck and Faber, Hauniae et Lipsiae [Copenhagen and Leipzig].

Murray J. \& Clarke B. 1966. The inheritance of polymorphic shell characters in Partula. Genetics 54: 1261-1277.

Myers N., Mittermeier R.A., Mittermeier C.G., da Fonseca G.A.B. \& Kent J. 2000. Biodiversity hotspots for conservation priorities. Nature 403: 853-858. https://doi.org/10.1038/35002501

Panha S. 1996. A checklist and classification of the terrestrial pulmonate snails of Thailand. Walkerana 8: $31-40$.

Pfeiffer L. 1861a. Descriptions of new land-shells, in the collection of H. Cuming, Esq. Proceedings of the Zoological Society of London 29: 190-196. (Published in parts, dates follow Duncan 1937.) Available from http://biodiversitylibrary.org/page/28672714 [accessed 9 Sept. 2013].

Pfeiffer L. 1861b (1860-1866). Novitates Conchologicae. Series Prima Mollusca Extramarina, Vol. 2: 139-303, pls 37-72 (1861: 161-178, pls 43-48). Theodor Fischer Verlag, Kassel. (Published in parts, dates follow Johnson 1969.) Available from http://biodiversitylibrary.org/item/122926 [accessed 8 Jun. 2016].

Pfeiffer L. 1863a. Descriptions of thirty-six new land shells from the collection of H. Cuming, Esq. Proceedings of the Zoological Society of London 30 [1862]: 268-278. (Published in parts, dates follow Duncan 1937.) Available from http://biodiversitylibrary.org/page/28627248 [accessed 8 Sept. 2013].

Pfeiffer L. 1863b (1860-1866). Novitates Conchologicae. Series Prima Mollusca Extramarina, Vol. 2: 139-303, pls 37-72 (1863: 207-234, pls 55-60).Theodor Fischer Verlag, Kassel. (Published in parts, dates follow Johnson 1969.) Available from http://biodiversitylibrary.org/item/122926 [accessed 8 Jun. 2016].

Pilsbry H.A. 1895 (1893-1895). Manual of Conchology, Structural and Systematic, with Illustrations of the Species, Second Series, Volume 9. Academy of Natural Sciences, Philadelphia.

Pilsbry H.A. 1900. Manual of Conchology, Structural and Systematic, with Illustrations of the Species, Second Series, Volume 13. Academy of Natural Sciences, Philadelphia. Available from http:// biodiversitylibrary.org/item/16708 [accessed 1 Jan. 2013].

Pilsbry H.A. 1928. Review of Japanese land Mollusks-II. Proceedings of the Academy of Natural Sciences of Philadelphia 80: 119-145.

Richardson L. 1985. Camaenidae: catalog of species. Tryonia 12: 1-479.

Schileyko A.A. 2011. Check-list of land pulmonate molluscs of Vietnam (Gastropoda: Stylommatophora). Ruthenica 21: 1-68. Available from http://www.ruthenica.com/documents/vol21_Schileyko_1-68.pdf [accessed 9 Jan. 2013].

Solem A. 1959. Zoogeography of the land and fresh-water molluscs of the New Hebrides. Fieldiana, Zoology 43: 239-359. Available from http://biodiversitylibrary.org/item/21248 [accessed 8 Jun. 2016].

Solem A. 1965. Land snails of the genus Amphidromus from Thailand (Mollusca: Pumonata: Camaenidae). Proceedings of the United States National Museum 117: 615-628. Available from http:// biodiversitylibrary.org/page/7759057 [accessed 8 Jun. 2016]. 
Solem A. 1983. First record of Amphidromus from Australia with anatomical note on several species (Mollusca: Pulmonata: Camaenidae). Records of the Australian Museum 35: 153-166.

Sutcharit C. \& Panha S. 2006. Taxonomic review of the tree snail Amphidromus Albers, 1850 (Pulmonata: Camaenidae) in Thailand and adjacent areas: Subgenus Amphidromus. Journal of Molluscan Studies 72 : 1-30. https://doi.org/10.1093/mollus/eyi044

Sutcharit C., Asami T. \& Panha S. 2007. Evolution of whole-body enantiomorphy in the tree snail genus Amphidromus. Journal of Evolutionary Biology 20: 661-672. https://doi.org/10.1111/j.14209101.2006.01246.x

Sutcharit C., Ablett J., Tongkerd P., Naggs F. \& Panha S. 2015. Illustrated type catalogue of Amphidromus Albers, 1850 in the Natural History Museum, London, and descriptions of two new species. ZooKeys 492: 49-105. https://doi.org/10.3897/zookeys.492.8641

Thach N.N. 2014. A new Amphidromus (Gastropoda: Camaenidae) from Vietnam. Gloria Maris 53: $38-42$.

Thach N.N. 2015. Amphidromus setzeri, a new species (Gastropoda: Camaenidae) from Vietnam. Gloria Maris 53: 56-58.

Thach N.N. \& Huber F. 2014. A new Amphidromus (Gastropoda: Camaenidae) from Vietnam. Basteria 78: $35-37$.

Vermeulen J.J., Liew T.-S. \& Schilthuizen M. 2015. Additions to the knowledge of the land snails of Sabah (Malaysia, Borneo), including 48 new species. ZooKeys 531: 1-139. https://doi.org/10.3897/ zookeys.531.6097

Wiegmann F. 1894. Beiträge zur Anatomie der Landschnecken des Indischen Archipels. In: Webber M. (ed.) Zoologische Ergebnisse einer Reise in Niederländisch Ost-Indien 3: 112-259. Available from http://biodiversitylibrary.org/page/47774902 [accessed 8 Jun. 2016].

Wu S.-H., Hwang C.-C. \& Lin Y.-S. 2008. Systematic revision of the arboreal snail Satsuma albida species complex (Mollusca: Camaenidae) with description of 14 new species from Taiwan. Zoological Journal of the Linnean Society 154: 437-493. https://doi.org/10.1111/j.1096-3642.2008.00415.x

Zilch A. 1953. Die Typen und Typoide des Natur-Museums Senckenberg 10: Mollusca, Pleurodontidae (1). Archiv für Molluskenkunde 82: 131-140.

Zilch A. 1960. Gastropoda, Euthyneura. In: Schindewolf O.H. (ed.) Handbuch der Paläozoologie 6: 601-834. Gebrüder Borntraeger, Berlin.

Manuscript received: 9 June 2016

Manuscript accepted: 5 September 2016

Published on: 13 June 2017

Topic editor: Rudy Jocqué

Section editor : Kurt Jordaens

Desk editor: Kristiaan Hoedemakers

Printed versions of all papers are also deposited in the libraries of the institutes that are members of the EJT consortium: Muséum national d'Histoire naturelle, Paris, France; Botanic Garden Meise, Belgium; Royal Museum for Central Africa, Tervuren, Belgium; Natural History Museum, London, United Kingdom; Royal Belgian Institute of Natural Sciences, Brussels, Belgium; Natural History Museum of Denmark, Copenhagen, Denmark; Naturalis Biodiversity Center, Leiden, the Netherlands; Museo Nacional de Ciencias Naturales-CSIC, Madrid, Spain; Real Jardín Botánico de Madrid CSIC, Spain. 